NBER WORKING PAPER SERIES

\title{
RISING GOVERNMENT DEBT: \\ CAUSES AND SOLUTIONS FOR A DECADES-OLD TREND
}

\author{
Pierre Yared \\ Working Paper 24979 \\ http://www.nber.org/papers/w24979 \\ NATIONAL BUREAU OF ECONOMIC RESEARCH \\ 1050 Massachusetts Avenue \\ Cambridge, MA 02138 \\ August 2018
}

I would like to thank Marina Azzimonti, V.V. Chari, Steve Coate, François Geerolf, Marina Halac, Andrew Hertzberg, Leo Martinez, Chris Moser, Suresh Naidu, Ziad Obermeyer, Facundo Piguillem, Ken Rogoff, Jesse Schreger, Christoph Trebesch, and Alan Viard for comments. Trisha Sinha and George Vojta provided excellent research assistance. The views expressed herein are those of the author and do not necessarily reflect the views of the National Bureau of Economic Research.

NBER working papers are circulated for discussion and comment purposes. They have not been peerreviewed or been subject to the review by the NBER Board of Directors that accompanies official NBER publications.

(C) 2018 by Pierre Yared. All rights reserved. Short sections of text, not to exceed two paragraphs, may be quoted without explicit permission provided that full credit, including $\odot$ notice, is given to the source. 
Rising Government Debt: Causes and Solutions for a Decades-Old Trend

Pierre Yared

NBER Working Paper No. 24979

August 2018, Revised January 2019

JEL No. D02,E62,H21,H6

\begin{abstract}
$\underline{\text { ABSTRACT }}$
Over the past four decades, government debt as a fraction of GDP has been on an upward trajectory in advanced economies, approaching levels not reached since World War II. While normative macroeconomic theories can explain the increase in the level of debt in certain periods as a response to macroeconomic shocks, they cannot explain the broad-based long-run trend in debt accumulation. In contrast, political economy theories can explain the long-run trend as resulting from an aging population, rising political polarization, and rising electoral uncertainty across advanced economies. These theories emphasize the time-inconsistency in government policymaking, and thus the need for fiscal rules that restrict policymakers. Fiscal rules trade off commitment to not overspend and flexibility to react to shocks. This tradeoff guides design features of optimal rules, such as information dependence, enforcement, cross-country coordination, escape clauses, and instrument vs. target criteria.
\end{abstract}

Pierre Yared

Columbia University

Graduate School of Business

3022 Broadway, Uris Hall 823

New York, NY 10027

and NBER

pyared@columbia.edu 


\section{Introduction}

Since reaching a trough in the mid-1970s, U.S. government debt as a fraction of GDP has been on an upward trajectory, approaching levels not reached since World War II. As Figure 1 illustrates, the government debt increase in World War II, as in other wars, was only temporary; the post-war reduction in defense spending facilitated its repayment. ${ }^{1,2}$ In contrast, the more recent increase in government debt reflects a long-term fiscal imbalance. Figure 2 shows that recent decades have been marked by large gaps between government spending and revenue. This is largely the result of a secular expansion of government spending - in particular, mandatory spending programs such as social security, medicare, and medicaid — and an inability for tax revenue to rise as rapidly. ${ }^{3}$

Figure 1. Government Debt in the U.S.

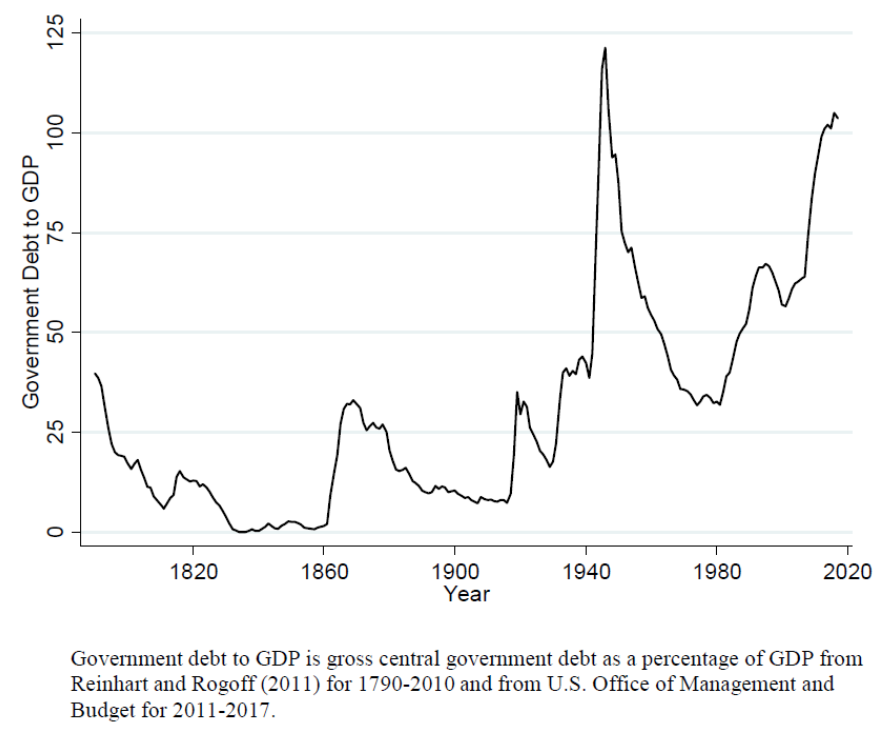

\footnotetext{
${ }^{1}$ The government debt to GDP ratio is projected to continue to increase significantly over the coming decade (Congressional Budget Office, 2018, Table 4.1).

${ }^{2}$ Throughout this paper, I focus on gross central government debt, since this measure is available for the broadest cross-section of advanced economies. All empirical observations are robust to replacing this gross measure with federal debt held by the public for the case of the U.S.

${ }^{3}$ See Blahous (2013) for a discussion of the impact of mandatory spending programs on rising government debt. Mandatory spending relative to GDP increased from 1970 onward, with a rapid acceleration between 1970 and the mid-1980s. Discretionary spending relative to GDP steadily declined from 1970 to 2000. Between 2000 and 2010, it increased (though remaining well below historical levels) and has been decreasing since 2010. See Congressional Budget Office (2018).
} 
Figure 2. Government Spending and Revenue in the U.S.

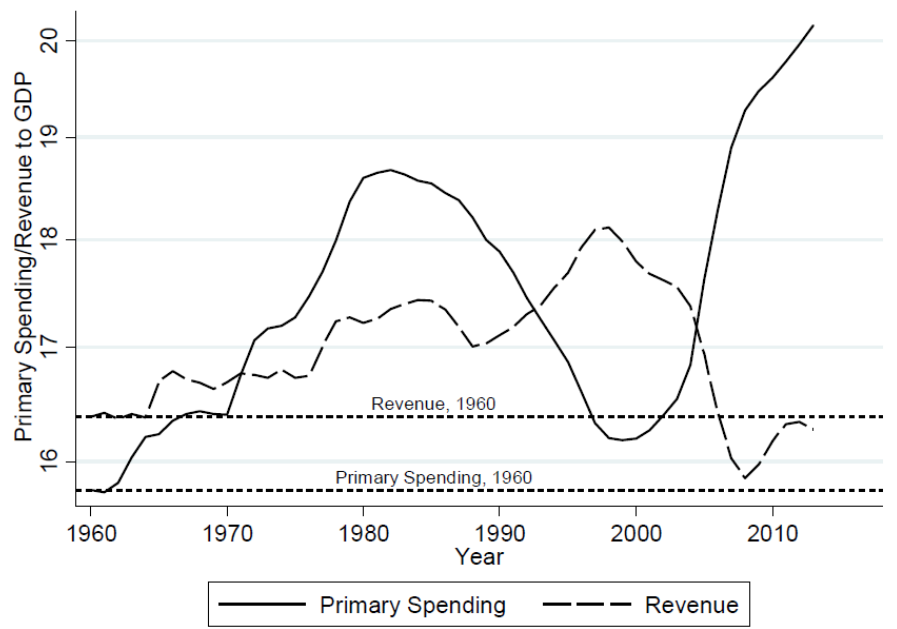

Primary spending is federal net outlays minus interest as a percentage of GDP and revenue is federal receipts as a percentage of GDP, both from U.S. Office of Management and Budget. Both series represent a 10-year moving average.

The U.S. is not alone. Almost every single advanced economy has experienced a longterm increase in government debt to GDP, including France and Germany; see Figure 3. The increase in government debt in most of these countries is the result of tax revenue not keeping pace with the expansion of government spending, as in the case of the U.S. ${ }^{4}$ In addition, across advanced economies, off-balance-sheet government liabilities, such as future government commitments to the old, have grown substantially. ${ }^{5}$

Debt buildups of the magnitude shown in Figure 3 can eventually lead to diminished economic activity, either by crowding out private capital investment or by forcing an increase in distortive taxes and decrease in public investment to facilitate repayment. ${ }^{6}$ Moreover, a government carrying such a high debt load may be constrained in responding to future catastrophes, such as financial crises, natural disasters, or wars. ${ }^{7}$ In extreme

\footnotetext{
${ }^{4}$ For example, between 1965 and 2016, general government tax revenue as a share of GDP increased in France and Germany and in the Organisation for Economic Cooperation and Development (OECD) more broadly (see OECD "Revenue Statistics").

${ }^{5}$ Hamilton (2014) estimates that in 2012, off-balance-sheet U.S. federal debt was six times the size of on-balance-sheet debt. More than three quarters of this off-balance-sheet debt was accounted for by future social security and medicare obligations (see Hamilton, 2014, Table 5). The European Central Bank (2011, Tables 4 and 11) estimates that in 2007, future pension entitlements in the Euro area were five times the size of on-balance-sheet debt.

${ }^{6}$ For an analysis of the empirical relationship between economic growth and public debt, see Reinhart, Reinhart, and Rogoff (2012) and Eberhardt and Presbitero (2015). Boskin, et al. (2018) assess the risks of rising debt in the U.S.

${ }^{7}$ For a discussion of this constraining effect of higher public debt, see Obstfeld (2013), Battaglini and
} 
cases, the result is default through explicit debt repudiation or inflation. ${ }^{8}$

Figure 3. Government Debt in Advanced Economies

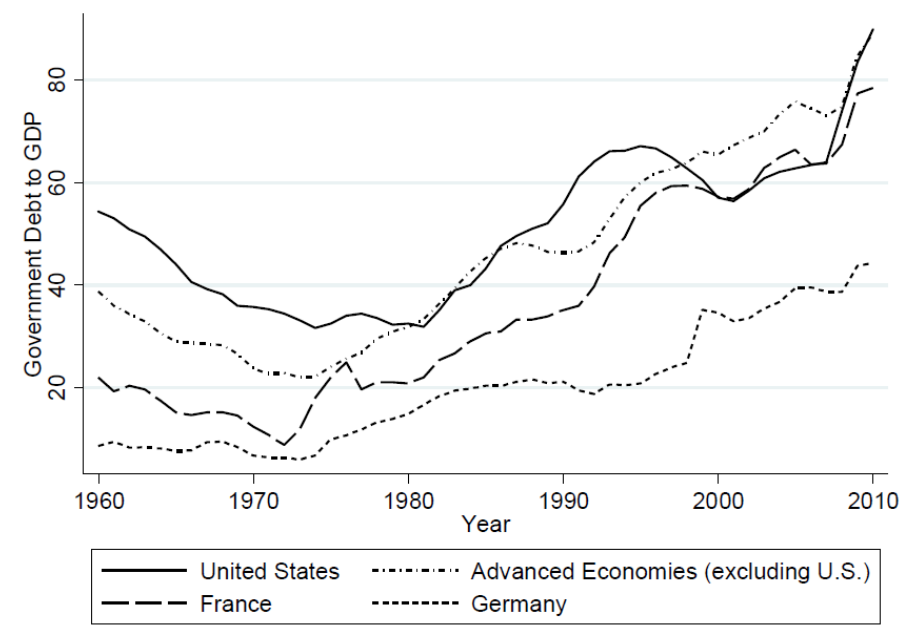

Government debt to GDP is gross central government debt as a percentage of GDP from Reinhart and Rogoff (2011). GDP is from from Feenstra, Inklaar, and Timmer (2015).

The sample of advanced economies is a balanced panel which includes Australia, Austria, Belgium, Canada, Denmark, Finland, France, Germany, Greece, Iceland, Ireland, Italy, Japan, Netherlands, New Zealand, Norway, Portugal, Spain, Sweden, Switzerland, United Kingdom, and United States. The line for advanced economies (excluding the U.S.) represents the GDP-weighted average for each observation year.

Could the costs of increased government debt - however large or small — be justified? Has the rise in government debt over the past four decades served a socially beneficial purpose that would compensate for the added debt burden? In the first part of this article, I review normative macroeconomic theories in which government debt serves three possible functions: it can facilitate tax-smoothing, provide a safe asset, or sustain dynamic efficiency. I argue that, while the increase in the level of debt in certain periods may have been an optimal response to specific macroeconomic shocks, such as the global financial crisis, the broad-based long-run trend in debt accumulation seems inconsistent with optimal policy. ${ }^{9}$

Motivated by this observation, I proceed in the second part of this article by reviewing political economy theories of government debt. These theories predict that the presence of an aging population, political polarization, and electoral uncertainty cause governments Coate (2016), and Romer and Romer (2017), among others.

${ }^{8}$ There are many historical cases of default in advanced economies (e.g., Reinhart, Reinhart, and Rogoff, 2015). The costs of default include increased stress on financial institutions, lower international financing for firms, and decreased export market access. For a discussion, see Borensztein and Panizza (2008), Tomz and Wright (2013), and Hébert and Schreger (2017), among others.

${ }^{9}$ Declining interest rates due to global imbalances after the Asian financial crisis of 1997 is another force which could have increased the optimal level of public debt, depending on the relative importance of different economic channels. 
to be shortsighted and to promote immediate goals at the expense of long-term ones. These political factors affect the long-run size of government deficits and therefore the long-term trajectory of government debt. I argue that an increasingly older population, rising political polarization, and rising electoral uncertainty can explain the long-run trend in government debt across advanced economies.

A resonating theme across all the political explanations for rising debt is the timeinconsistency of government policy. Current governments want to be fiscally irresponsible, while simultaneously hoping that future governments be fiscally responsible. This force explains why governments across the world have been compelled to adopt fiscal rulessuch as mandated deficit, spending, or revenue limits - to restrict future fiscal policy and curtail the increase in government debt. In 2015, 92 countries had fiscal rules in place, a dramatic increase from 1990, when only 7 countries had them. ${ }^{10}$ In some countries, these rules have been an effective force at limiting the deficit bias of governments and curbing the increase in debt. ${ }^{11}$

Given their prevalence, an important question concerns the optimal structure of fiscal rules, as well as the practical challenges to their implementation. In the final part of this article, I describe some of the recent research on the optimal design of fiscal rules, elucidating the fundamental tradeoff between commitment and flexibility underpinning these rules. I also consider what this tradeoff implies for various features of fiscal rules in theory and in practice. This discussion touches on how rules should be conditioned on public information, how they should be enforced, how they should be applied at a supranational level, whether they should feature escape clauses, and whether they should be based on fiscal policy tools or targets.

\section{Rising Government Debt vs. Optimal Policy}

Is rising government debt in advanced economies like the U.S. a reflection of optimal policy? In this section, I review theories of optimal government debt, and I argue that the answer to this question appears to be no. While the increase in the level of debt in certain periods may have been an optimal response to specific macroeconomic shocks, the broad-based long-run trend in debt accumulation seems inconsistent with optimal policy.

\footnotetext{
${ }^{10}$ For a complete description of the fiscal rule adopted in each country, see Lledó, et al. (2017).

${ }^{11}$ See Caselli et al. (2018) for a discussion.
} 


\subsection{How Government Debt Matters}

Behind any theory of optimal government debt is an assumption to break the Ricardian Equivalence proposition (Barro, 1974). This proposition states that the level of government debt is irrelevant and has no effect on real economic activity. Specifically, if the government cuts taxes and borrows today, the private sector anticipates a tax increase in the future by the government to repay the debt. As a consequence, consumption, labor, and capital investment decisions are unchanged since the private sector uses the tax cut today to save through government bonds to finance a higher future tax burden.

The logic of Ricardian Equivalence requires three strong conditions that do not hold in practice. First, it assumes that raising revenue entails no deadweight loss, which is why the timing of revenue-raising does not directly distort consumption, labor, or capital investment decisions. Second, households and firms are assumed to be financially unconstrained and can thus borrow and lend freely at the same terms as the government. This is why a borrowing entity does not benefit from the additional liquidity it receives from a tax cut. Finally, households and firms care about the level of taxes infinitely far into the future, which is why they internalize the future tax liability associated with current tax cuts. I now turn to theories of optimal government debt that relax each of these three conditions.

\subsection{Tax-Smoothing}

The most widely used theory of optimal government debt management is the tax-smoothing theory. If raising revenue distorts economic decisions, whereas selling government bonds does not, then government debt allows the government to smooth the deadweight loss from raising revenue across time (e.g., Barro, 1979, Lucas and Stokey, 1983). ${ }^{12,13}$ According to this theory, there are a number of economic forces that drive optimal government debt upward or downward. I now examine whether this theory of optimal policy can justify the observed long-run trend in government debt in advanced economies.

\footnotetext{
${ }^{12}$ One can introduce such a deadweight loss in a production economy by ruling out lump sum taxes. This implies that raising revenue through distortionary taxes changes the level, and potentially the distribution, of economic allocations.

${ }^{13}$ For follow-up work which builds on this tradition, see Bohn (1990), Chari, Christiano, and Kehoe (1994), Aiyagari, et al. (2002), Angeletos (2002), Buera and Nicolini (2004), Werning (2007), Lustig, Sleet, and Yeltekin (2008), Faraglia, Marcet, and Scott (2010), Farhi (2010), Bhandari, et al. (2017a), and Karantounias (2018), among others.
} 


\subsubsection{Unanticipated Fiscal Needs}

The tax-smoothing argument suggests that a government facing temporary and unanticipated spending needs should respond optimally by increasing government debt. The logic is that financing these needs through immediate revenue-raising would be too costly for the economy in the short-term; it is better to issue debt to spread these costs into the future, when fiscal needs are lower. There are several unanticipated temporary fiscal needs that have caused government debt to increase across advanced economies.

The global financial crisis, which started in 2007, increased the fiscal needs of governments. It put downward pressure on government revenues and upward pressure on the potential benefits of fiscal stimulus, which some countries pursued through temporary tax cuts and government spending increases. ${ }^{14}$ Government debt across advanced economies increased in response. In the U.S., gross central government debt as a fraction of GDP increased from 64 percent in 2007 to 90 percent in 2010. During the same time frame, government debt to GDP in the Euro area also increased, not only in countries heavily impacted by the crisis such as Greece, Ireland, Italy, Portugal, and Spain, but also in countries less impacted by the crisis such as Germany and France. ${ }^{15}$

Nevertheless, the global financial crisis alone cannot explain the secular increase in government debt across advanced economies, as this trend goes back several decades. In 1980, U.S. government debt was about one half the pre-crisis 2007 level. In France and Germany, government debt to GDP was approximately one third the 2007 level.

Prior to the global financial crisis, the unanticipated wars in Afghanistan (2001present) and Iraq (2003-2011) contributed to rising government debt. In the U.S., military spending as a fraction of GDP increased from 2.9 percent in 2000 to 3.8 percent in 2007, and government debt to GDP increased from 57 percent to 64 percent. $^{16}$

However, the wars in Afghanistan and Iraq cannot account for the increase in U.S. government debt to GDP from 33 percent in 1980 to 57 percent in 2000. This was a period during which the end of the Cold War brought along a significant unanticipated decrease in military spending, a force that should have caused government debt to decline, but did not (e.g., Alesina, 2000). In addition, these wars cannot account for the increase in government debt in other advanced economies. For example, military spending relative to GDP actually decreased between 2000 and 2007 in the Euro area as a whole, including

\footnotetext{
${ }^{14}$ See Ramey (2011) and the references therein for a discussion of the empirical evidence on the benefit of fiscal stimulus measures.

${ }^{15}$ All measures of gross central government debt to GDP are from Reinhart and Rogoff (2011).

${ }^{16}$ Military spending as a fraction of GDP is from World Bank.
} 
in Germany and France. ${ }^{17}$ Nonetheless, government debt relative to GDP increased for many Euro area countries, including in Germany and France. ${ }^{18}$

In sum, unanticipated temporary fiscal needs resulting from the global financial crisis and war can explain the increase in the level of debt in certain periods, but they cannot explain the long-term trend in government debt across advanced economies.

\subsubsection{Anticipated Fiscal Needs}

A question then emerges as to whether anticipated fiscal needs can explain the longterm trend in public debt. According to tax-smoothing theory, a government facing a reduction in long-term fiscal needs should increase public debt in the present. This is because declining fiscal pressures can facilitate future debt repayment.

The long-term anticipated fiscal needs of advanced economies have actually evolved in the exact opposite direction. Across advanced economies, the reduction in fertility rates and the extension of life spans have gradually increased the fraction of the population which is old, as displayed in Figure 4. The result is higher dependency ratios and larger old-age government assistance programs. ${ }^{19}$ In the U.S., for example, social security spending as a fraction of GDP increased from 2.8 percent of GDP in 1970 to 4.9 percent of GDP in 2017. Medicare spending as a fraction of GDP increased from 0.6 percent of GDP to 3.7 percent of GDP during that time. ${ }^{20}$ These are forecasted to continue to rise over the coming decade. ${ }^{21}$

In the face of these anticipated demographic changes, tax-smoothing theory would have prescribed a decumulation - not an accumulation - of government debt during the past several decades. A government facing rising future fiscal pressures should pay down a larger portion of the debt in the present so as to alleviate forecasted fiscal strain. Moreover, tax-smoothing theory would have predicted lower debt accumulation in countries anticipating greater strain due to an aging population. Nevertheless, the cross-sectional

\footnotetext{
${ }^{17}$ Military spending decreased in the Euro area from 1.9 percent to 1.7 percent of GDP. In Germany, the decline was from 1.4 percent to 1.2 percent of GDP. In France, the decline was from 2.5 percent to 2.2 percent of GDP.

${ }^{18}$ In Germany, government debt increased from 35 percent to 39 percent of GDP. In France, government debt increased from 57 percent to 64 percent of GDP.

${ }^{19}$ For example, between 1975 and 2015, the dependency ratio in the OECD increased from 19.5 to 27.9 (OECD, 2017, Table 5.5). Between 1980 and 2013, cash benefits to the elderly as a fraction of GDP increased from 5.7 percent to 8.2 percent (OECD "Social Expenditure Database").

${ }^{20}$ Data from Congressional Budget Office (2018). This increase in mandatory spending was anticipated by historical U.S. government forecasts which, on average, predicted larger increases than were realized (see Congressional Budget Office, 2017).

${ }^{21}$ Social security spending is projected to increase to 6.0 percent of GDP and medicare spending to 5.1 percent of GDP by 2028 (Congressional Budget Office, 2018, Table 2.1).
} 
data illustrated in Figure 5 shows the opposite: Countries experiencing a greater increase in population aging, like Japan, actually accumulated more debt as a percentage of GDP than those experiencing a lower demographic strain, such as Denmark.

In sum, the long-term secular trend in government debt accumulation across advanced economies cannot reflect an optimal policy response to anticipated fiscal needs.

Figure 4. Aging Population in Advanced Economies

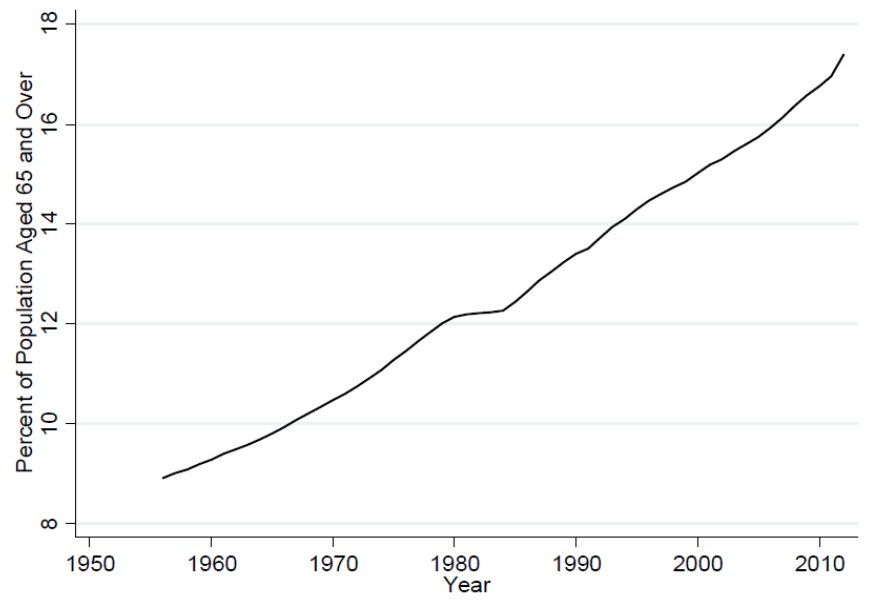

Percent of population aged 65 and over is from OECD. Total population is from Feenstra, Inklaar, and Timmer (2015). The sample represents the balanced panel of advanced

economies from Figure 3. The line represents the population-weighted average for each observation year.

Figure 5. Change in Government Debt and Change in Elderly Population

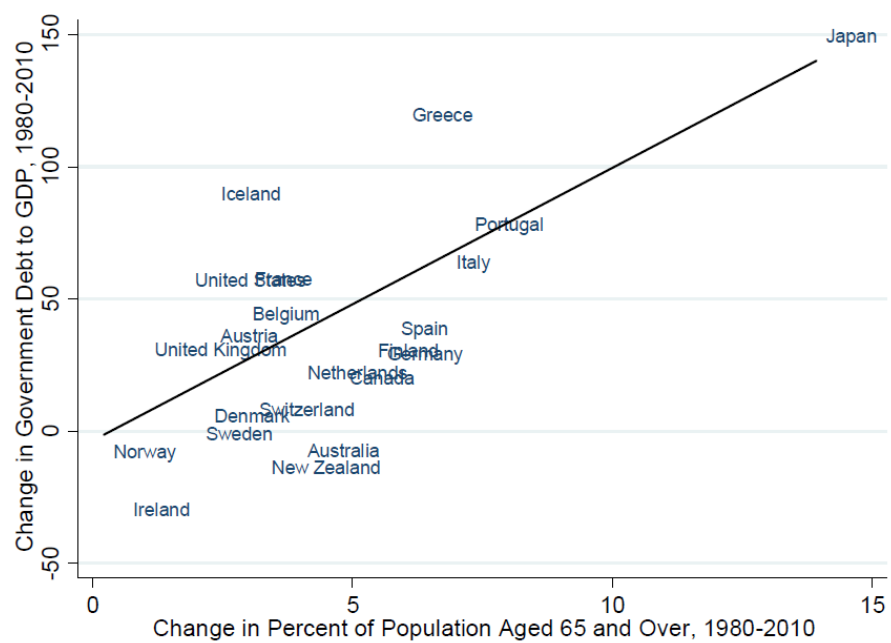

Government debt to GDP is gross central government debt as a percentage of GDP from Reinhart and Rogoff (2011). Percent of population aged 65 and over is from OECD. The sample represents advanced economies from Figure 3 . The regression represented by the fitted line yields a coefficient of 10.32 (standard error $=2.37$ ), $N=22$, and $R^{2}=0.49$. 


\subsection{Safe Asset Provision}

A second theory of optimal government debt considers the role of public debt when the private sector is financially constrained and cannot borrow or lend freely at the same terms as the government (e.g., Woodford, 1990, Aiyagari and McGrattan, 1998, Holmström and Tirole, 1998). ${ }^{22}$ This theory builds on the fact that, relative to private defaultable debt, government debt is less risky to hold since it is backed by future tax revenues, which the government can collect through its power of coercion. By increasing the issuance of government bonds, the government slackens financial constraints on borrowers who now receive additional resources from the government (through tax cuts or government loans), while simultaneously increasing the supply of safe assets available to lenders. Accordingly, the government can accommodate a change in safe asset demand or supply — which affects interest rates - with an increase or decrease in government debt. I now examine whether this safe asset provision theory of optimal debt can justify the observed long-term trend in government debt in advanced economies. ${ }^{23}$

\subsubsection{Financial Constraints}

The safe asset provision theory suggests that, in the face of tightening private credit conditions, the government should respond with an increase in government debt. If financial constraints become tighter, an increase in public debt counteracts the shrinking supply of safe assets for creditors, while simultaneously providing more liquidity to increasingly constrained borrowers. ${ }^{24}$

From this perspective, the increase in public debt in response to the global financial crisis previously described is qualitatively consistent with the conduct of optimal policy. However, the logic of this argument is not consistent with the secular increase in public debt in the decades prior to the global financial crisis. Between 1980 and 2007, financial conditions did not tighten, but actually loosened through a global process of financial

\footnotetext{
${ }^{22}$ For follow-up work which adds on this tradition, see Mankiw (2000), Yared (2013), Azzimonti, de Francisco, and Quadrini (2014), Angeletos, Collard, and Dellas (2016), Bhandari, et al. (2017b), and Azzimonti and Yared (2017, 2018), among others.

${ }^{23}$ For this exercise, I consider the implications for an economy with heterogeneous households consisting of borrowers and lenders. An alternative approach considers hand-to-mouth homogeneous households in an open economy. Since the government's objective in this case is to smooth private consumption over time through taxes and transfers matched with fluctuating government borrowing from abroad, the analysis of this environment is isomorphic to a tax-smoothing framework. For further discussion on the isomorphism between tax-smoothing and consumption-smoothing frameworks, see Barro (1979) and Aiyagari et al. (2002).

${ }^{24}$ Azzimonti and Yared (2018) establish this comparative static quantitatively when evaluating the stationary distribution of an economy along a balanced growth path.
} 
deregulation (e.g., Philippon and Reshef, 2012). Deregulation came hand in hand with an increase in private sector leverage. ${ }^{25}$ According to the safe asset provision theory, such a relaxation of financial constraints should have been met with a decrease, as opposed to an increase, in public debt.

\subsubsection{Precautionary Private Savings}

The safe asset provision theory also suggests that public debt should increase in response to rising income risk. Households and businesses facing greater income risk develop a stronger precautionary motive to save, driving down interest rates. The optimal policy response increases the supply of public debt to satisfy the increased demand for safe assets. $^{26}$

Nevertheless, evidence from U.S. administrative data suggests that income risk actually declined in the decades after 1980 (e.g., Sabelhaus and Song, 2010, Guvenen, Ozkhan, and Song, 2014). ${ }^{27}$ According to the safe asset provision theory, this development should have been met with a decrease, as opposed to an increase, in public debt.

\subsubsection{Global Capital Flows and Interest Rates}

A final factor which the safe asset provision theory can address is how public debt should respond to globalization. Over the last four decades, the reduction of international barriers in trade and finance led to a dramatic expansion of cross-border flows. ${ }^{28}$ This trend accelerated in the aftermath of the Asian financial crisis of 1997 and the introduction of China into the World Trade Organization in 2001. The ensuing large capital inflows into advanced economies - a phenomenon known as the global saving glut - led to a deterioration of net foreign asset position for some advanced economies and to a decline in global interest rates (Bernanke, 2005). ${ }^{29}$

What is the effect of globalization on the optimal provision of public debt? How should public debt respond to larger capital inflows from global saving glut countries? The answer

\footnotetext{
${ }^{25}$ The U.S., for example, saw an increase in household debt, with household debt service as a percent of disposable income rising from 10.5 percent in 1980 to 13 percent in 2007 (see Federal Reserve Board).

${ }^{26}$ Azzimonti, de Francisco, and Quadrini (2014) illustrate this result in a quantitative model.

${ }^{27}$ This evidence pertains to household labor income. Business-level analyses of trends in risk have found mixed results (e.g., Campbell, et al, 2001, and Brandt, et al., 2009).

${ }^{28}$ For example, between 1980 and 2017, U.S. foreign assets increased from 30 percent of GDP to 144 percent of GDP while U.S. foreign liabilities increased from 19 percent of GDP to 185 percent of GDP (U.S. Bureau of Economic Analysis, "International Investment Position", Table 1.1).

${ }^{29}$ In the U.S., for instance, net foreign assets relative to GDP declined from -9 percent of GDP in 1997 to -41 percent of GDP in 2017 (U.S. Bureau of Economic Analysis, "International Investment Position", Table 1.1).
} 
depends on a number of factors. First, an increase in asset demand by foreigners cheapens borrowing by the domestic private and public sectors, reducing the level of interest rates. Second, globalization expands the market for safe assets, thereby reducing the marginal interest rate response to additional public debt issuance. Finally, additional borrowing by the domestic private sector (in response to lower interest rates) means that domestic borrowers suffer more from marginal interest rate increases induced by higher public debt. While the first two forces reduce the cost of issuing public debt on the margin, the third force increases this cost. As such, the optimal policy response to greater globalization and capital inflows is ambiguous. ${ }^{30}$

Beyond this theoretical ambiguity, there are other reasons why the long-term trend in public debt across advanced economies does not appear to be an optimal policy response to globalization. First, government debt in the U.S. and other advanced economies had been on an upward trajectory well before the onset of the global saving glut in the late $1990 \mathrm{~s} .{ }^{31}$ Second, prior to the late 1990s, the degree of cross-border public debt holdings had been relatively stable, suggesting that the globalization of public debt markets was limited up until that point. ${ }^{32}$ Finally, this theory would predict that smaller countries respond to globalization by increasing public debt proportionately more than larger countries. This follows since globalization decreases the interest rate response to debt issuance by more for small countries. This prediction is also at odds with the empirical evidence. The relationship between country size and debt issuance for advanced economies during this period is actually positive, with larger economies such as Japan and the United States increasing their public debt to GDP ratio by more than other countries. ${ }^{33}$

\footnotetext{
${ }^{30}$ The three channels highlighted here, together with an ambiguous optimal policy response, emerge if one extends the two-period model of Azzimonti and Yared (2017) by introducing foreign asset demand (details available upon request). Azzimonti, de Francisco, and Quadrini (2014) also illustrate the second channel in a model with symmetric countries individually choosing policy. Another approach to this question additionally considers the risk of default and inflation by the government (e.g., Caballero, Farhi, and Gourinchas, 2017, Farhi and Maggiori, 2017, He, Krishnamurthy, and Milbradt, 2018, among others).

${ }^{31}$ See the discussion in the previous section for the case of the U.S. In Germany, government debt to GDP grew from 15 percent in 1980 to 35 percent in 2000. In France, it grew from 21 percent to 57 percent.

${ }^{32}$ For example, in the case of the U.S., the fraction of government debt which was domestically held remained around 79 percent between 1980 and 1994. Between 1994 and 2017, this fraction declined to 49 percent (see U.S. Department of the Treasury, Fiscal Service).

${ }^{33}$ As an illustration, in the advanced economy sample from Figure 3, the change in debt to GDP from 1980 to 2010 has a correlation of 0.26 with $\log 1980$ population and 0.23 with $\log 1980$ GDP. Population and GDP data are from Feenstra, Inklaar, and Timmer (2015).
} 


\subsection{Dynamic Efficiency}

I have argued that neither the tax-smoothing theory nor the safe asset provision theory can deliver a justification for the long-term trend in government debt accumulation across advanced economies. A final, less explored, theory considers the role of public debt when the private sector does not internalize the effect of fiscal policy infinitely far into the future (e.g., Diamond, 1965, and Blanchard, 1985). In such an environment, older households do not face the future tax cost of issuing government debt today, since these taxes will be repaid by future generations. As a consequence, an increase in government debt has the effect of tilting the lifetime consumption profile towards older generations, while also increasing interest rates and crowding out capital investment. Moreover, under some conditions, the possibility of a bubble in government debt arises, whereby one generation is willing to hold government debt purely because future generations are also expected to do so.

From this perspective, if an economy is dynamically inefficient and has overaccumulated capital, increasing government debt can be optimal. ${ }^{34}$ By reducing the capital stock, a higher government debt reduces household saving and benefits society by increasing household lifetime consumption. However, there is no evidence of capital overaccumulation in advanced economies over the last decades. Abel, et al. (1989) examine data for the OECD from 1960 to 1985 and for the U.S. from 1929 to 1985 and find no dynamic inefficiencies. The empirical patterns behind their conclusions also hold for the U.S. with data extended to the present. ${ }^{35}$ This evidence suggests that the observed trend in public debt is unlikely to have been an optimal policy response to dynamic inefficiency. ${ }^{36}$

\section{Political Forces behind Rising Government Debt}

The absence of a clear normative reason for the trend in government debt across advanced economies suggests that political forces are behind this pattern. In this section, I review political economy theories of government debt. These theories predict that the presence of an aging population, political polarization, and electoral uncertainty cause governments to be shortsighted and to promote immediate goals at the expense of long-term ones. These political factors affect the long-run size of government deficits and therefore the

\footnotetext{
${ }^{34}$ Inefficient overaccumulation can emerge in equilibrium when agents have finite horizons, in which case a bubble on government debt can improve welfare. See Shell (1971) and Geanakoplos (2008) for a discussion of inefficiencies in overlapping generations economies.

${ }^{35}$ See Geerolf (2017), Figure 3.

${ }^{36}$ Geerolf (2017) revisits the conclusions of Abel el al. (1989) and argues that some OECD countries, such as Japan and South Korea, are dynamically inefficient.
} 
long-term trend of government debt. I argue that, over the past four decades, changes in these political factors can explain the long-run trajectory of government debt. ${ }^{37}$

Theoretically, the political factors that I describe imply that a government behaves similarly to an agent with present-biased and dynamically inconsistent preferences (e.g., Strotz, 1955). An analytically tractable representation of such preferences is the quasihyperbolic case analyzed in Phelps and Pollak (1968) and Laibson (1997). ${ }^{38}$ In the context of a fiscal policy model, quasi-hyperbolic preferences imply that the government at a given date $t$ weighs periods $\{t, t+1, t+2, \ldots\}$ according to discount rates $\left\{1, \beta \delta, \beta \delta^{2}, \ldots\right\}$, for some rate of time preference $\delta \in(0,1)$ and present bias $\beta \in(0,1)$. This present bias is determined by various underlying political factors. ${ }^{39}$

Relative to the benevolent social planner, with discount rates $\left\{1, \delta, \delta^{2}, \ldots\right\}$, these quasihyperbolic preferences feature a sharp drop in valuation after date $t$, capturing the present bias. Moreover, these preferences are dynamically inconsistent: The weight the government assigns to future periods depends on the perspective of the government. For example, consider the weight the government assigns to date $t+2$ relative to date $t+1$. From the perspective of date $t$, this weight is $\left(\beta \delta^{2}\right) /(\beta \delta)=\delta$, but from the perspective of date $t+1$, this weight is $\beta \delta<\delta$. The date $t+1$ government is therefore more shortsighted than the date $t$ government would prefer.

In this framework, any political factor that amplifies the present bias (reduces $\beta$ ) results in larger deficits and changes the long-term trend in government debt. Moreover, since a government at any date would prefer to commit future governments to constraining the growth of debt, debt accumulation in this context reflects a political failure. ${ }^{40}$

In the next subsections, I describe the political factors that provide a microfoundation for the present bias and the dynamic inconsistency of government preferences. I argue

\footnotetext{
${ }^{37} \mathrm{My}$ discussion focuses on rational theories in which political self-interest drives debt accumulation. The "fiscal illusion" theory emphasizes voters' behavioral biases and their potential inability to understand the long-term costs of deficits (e.g., Buchanan and Wagner, 1977). This theory does not lead voters to demand commitment devices, such as the fiscal rules that have been adopted across the world (see the next section for a discussion). Moreover, it is not clear whether the time-series and cross-country patterns in behavioral biases-to the extent these could be measured-would explain the empirical evidence on public debt.

${ }^{38}$ For follow-up work on the analysis of quasi-hyperbolic preferences, see Krusell and Smith (2003), Bernheim, Ray, and Yeltekin (2015), Bisin, Lizzeri, and Yariv (2015), Chatterjee and Eyigungor (2016), Cao and Werning (2017), Lizzeri and Yariv (2017), and Moser and Olea de Souza e Silva (2017), among others.

${ }^{39}$ For fiscal policy applications that make use of these preferences, see Aguiar and Amador (2011) and Halac and Yared (2014, 2017, 2018a), for example.

${ }^{40}$ In contrast to a framework with an impatient, time-consistent government that overborrows, the quasi-hyperbolic model leads to a demand for commitment devices, such as the fiscal rules that governments have adopted across the world (see the next section for a discussion).
} 
that persistent, broad-based changes in these political factors offer an explanation for the long-run trend in government debt. ${ }^{41,42}$

\subsection{Aging and Heterogeneous Discounting}

Government debt is impacted by the fact that households differ in how much they weigh the present relative to the future. These differences can be the result of demographics, with older households caring less about the future than younger households. This heterogeneity by itself does not imply excessive debt accumulation. However, in a political environment in which policy is chosen sequentially without commitment, as in a representative democracy, this heterogeneity implies a present bias together with dynamically inconsistent preferences for the government.

We can illustrate this idea using a simple example based on the analysis in Jackson and Yariv $(2014,2015)$. Suppose that half the population has a rate of time preference $\delta_{H}$ and the other half has a rate $\delta_{L}<\delta_{H}$, with policy chosen sequentially by a utilitarian government. ${ }^{43}$ Individuals are time-consistent, since an individual applies discount rates $\left\{1, \delta_{i}, \delta_{i}^{2}, \ldots\right\}$ for $i=H, L$ to the future. However, the utilitarian government is presentbiased and dynamically inconsistent. To see why, consider the weight the utilitarian government assigns to date $t+2$ relative to date $t+1$. From the perspective of date $t$, this weight is $\left(\delta_{L}^{2}+\delta_{H}^{2}\right) /\left(\delta_{L}+\delta_{H}\right)$. However, from the perspective of date $t+1$, this weight is $\left(\delta_{L}+\delta_{H}\right) / 2<\left(\delta_{L}^{2}+\delta_{H}^{2}\right) /\left(\delta_{L}+\delta_{H}\right)$. Thus, the government overweighs date $t+1$ when choosing policy at date $t+1$ relative to what it would have preferred ex ante at date $t$. Note further that for the special case where $\delta_{L}=0$, government preferences exactly coincide with the quasi-hyberbolic preferences described previously, with a rate of time preference $\delta=\delta_{H}$ and a deficit bias $\beta=1 / 2$ (the fraction of patient households). ${ }^{44}$

\footnotetext{
${ }^{41}$ Due to space restrictions, I focus on long-run considerations and ignore variation in present bias over the political business cycle (e.g., Rogoff and Sibert, 1988, and Rogoff, 1990, Drazen, 2000, Ales, Maziero, and Yared, 2014). See the survey in Alesina and Passalacqua (2016) for a more detailed discussion of the theoretical literature on the political economy of public debt.

${ }^{42}$ Note that even in the absence of the forces that I describe, government debt can deviate from the normative benchmark if a government is benevolent but lacks commitment to the path of interest rates or to repaying debt (e.g., Chari and Kehoe 1993a, 1993b, Debortoli, Nunes, and Yared, 2017, 2018, among others). However, whether this form of lack of commitment on its own leads to debt that is higher or lower than is optimal is ambiguous and depends on various economic considerations. For this reason, I focus on how lack of commitment combined with additional political factors leads to excessive debt.

${ }^{43}$ This representation of sequential policymaking is equivalent to a policy chosen through dynamic elections in a probabilistic voting game (e.g., Farhi, et al., 2012).

${ }^{44}$ Jackson and Yariv $(2014,2015)$ generalize this idea and show that with any heterogeneity in preferences, every nondictatorial aggregation method that respects unanimity must be time-inconsistent; moreover, any such method that is time separable must lead to a present bias.
} 
Conceptually, heterogeneity in discount rates means that impatient households wield disproportionate influence in policymaking. If commitment were possible, impatient households would agree ex ante to allow the patient households to have more political influence in the future, since those households value the future more. However, nothing can stop impatient households from influencing policy ex post through the political process, which is why there is a present bias in policymaking, and the government is time-inconsistent.

This theory has implications for intergenerational conflict and its impact on government debt. The larger is the fraction of old impatient households relative to young patient households, the more shortsighted is the government, the larger are government deficits, and the more rapid is government debt accumulation. ${ }^{45}$ This is consistent with survey evidence on intergenerational differences in policy preferences, with younger households placing a larger value on fiscal responsibility than older households. ${ }^{46}$

This theory can explain the long-term trend in government debt in advanced economies as resulting from an aging population, as displayed earlier in Figure 4. In addition, this theory is consistent with the cross-country trends displayed earlier in Figure 5, where government debt has grown faster in countries experiencing a larger increase in the elderly population.

\subsection{Tragedy of the Commons}

A second political factor leading to shortsighted policymaking is the tragedy of the commons. According to this theory, political parties acting independently engage in excessive targeted government spending since they do not internalize the shared financing costs of government debt. ${ }^{47}$

As an illustration, consider $N$ symmetric parties that can make targeted deficitfinanced spending appropriations to their constituencies, simultaneously and without coordinating. Then each party fails to internalize the total cost of additional debt, since the burden of this debt is shared equally across parties in the future; the private cost of one additional unit of debt due to targeted spending is a fraction $1 / N$ of the total

\footnotetext{
${ }^{45}$ Arguments along these lines are made in Calvo and Obstfeld (1988), Cukierman and Meltzer (1989), and Tabellini (1991). Song, Storesletten, and Zilibotti (2012) show that this present bias can be mitigated if current generations care more about future generations than future generations care about current generations.

${ }^{46}$ See Parker (2012) and Wolter, et al. (2013).

${ }^{47}$ Weingast, Shepsle, and Johnsen (1981) discuss the common pool problem in a static fiscal framework. Tornell and Lane (1999), Velasco (1999, 2000), and Hertzberg (2016) discuss it in a dynamic framework where they show that it leads to lower aggregate saving.
} 
cost. The result is excessive spending and government debt accumulation, which would be alleviated if parties jointly committed ex ante to limiting borrowing. In this sense, the lack of coordination leads the government to be present-biased and time-inconsistent in its fiscal policy. ${ }^{48}$

This coordination problem can also emerge across countries, particularly if these countries are highly integrated financially, as in the Euro area. Individual countries may fail to internalize the impact of their borrowing decisions on the shared interest rates, inflation rates, or probability of financial contagion. The result is inefficiently high public debt accumulation across countries. ${ }^{49}$

The tragedy of the commons predicts that countries with a large number of constituencies or deep disagreements in spending priorities across constituencies will incur larger government deficits, resulting in faster government debt accumulation. ${ }^{50}$ This prediction is consistent with empirical work that has found that larger deficits are associated with countries with more ministers, with greater ideological polarization in the executive, and with a proportional (as opposed to majoritarian) election system. ${ }^{51}$

This theory can explain the long-term trend in government debt in advanced economies as a result of the increase in political polarization and fragmentation across advanced economies. Figure 6 displays the increase in partisan conflict in the U.S. since the late 1960s. This trend is consistent with evidence from other advanced economies, which have witnessed a declining influence of centrist political parties; see Figure $7 .^{52}$ Finally, across advanced economies, the rise in government debt has also mirrored the increase in political fractionalization in legislatures; see Figure $8 .^{53}$

\footnotetext{
${ }^{48}$ Under some assumptions on preferences, Hertzberg (2016) establishes an equivalence result which links the intertemporal behavior of multiple time-consistent agents suffering from the tragedy of the commons with that of a single time-inconsistent agent with quasi-hyperbolic preferences.

${ }^{49}$ Chang (1990), Azzimonti, de Francisco, and Quadrini (2014), and Halac and Yared (2018a) discuss excessive borrowing in the context of shared interest rates. Beetsma and Uhlig (1999), Chari and Kehoe (2007), and Aguiar, et al. (2015) discuss it in the context of shared inflation rates. These mechanisms also apply to subnational governments which can issue their own debt (e.g., Dovis and Kirpalani, 2017).

${ }^{50}$ Disagreement in a common pool model can be represented by the weight individual constituencies place on targeted transfers versus mutually beneficial public goods. See Hertzberg (2016) for additional details.

${ }^{51}$ See for example evidence in Woo (2003), Persson and Tabellini (2004) and Crivelli, et al. (2015).

${ }^{52}$ This pattern is principally driven by rising vote shares for far right political parties versus far left parties, which have maintained stable vote shares. See Betz (1994) and Ignazi (2003) for a discussion.

${ }^{53}$ Figures 7, 8, and 10 present data from Funke, Schularick, and Trebesch (2016) starting from 1950 to maximize the cross-section of countries in the balanced panel. Relative to the sample in Figure 3, the sample in these figures excludes Greece, Iceland, New Zealand, Portugal, and Spain, for which this political data is not available for all years. Figure 10 additionally excludes Finland due to lack of data.
} 
Figure 6. Rising Political Polarization in the U.S.

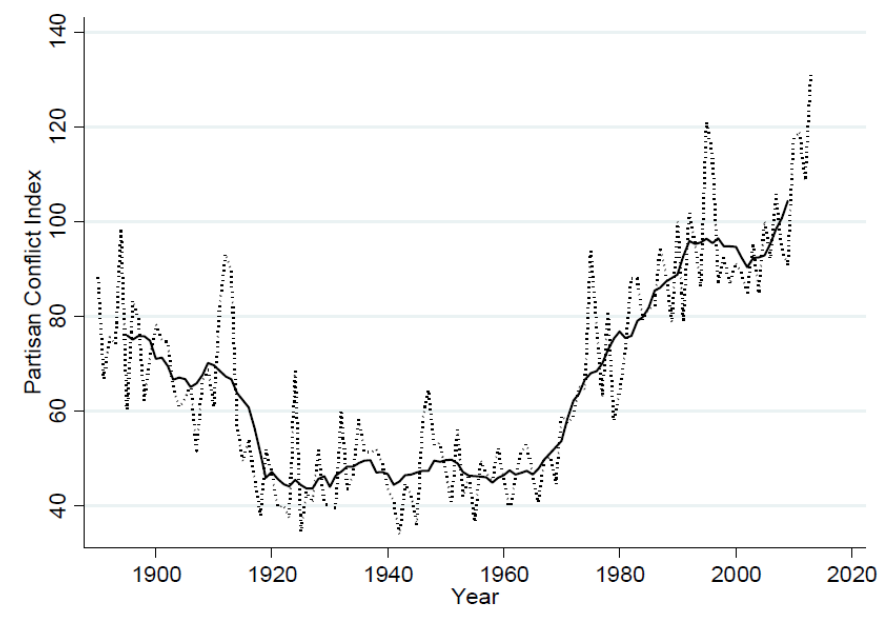

Partisan conflict index is from Azzimonti (2018). The dotted line is the annual observation. The solid line is the 10-year moving average.

Figure 7. Rising Political Polarization in Advanced Economies

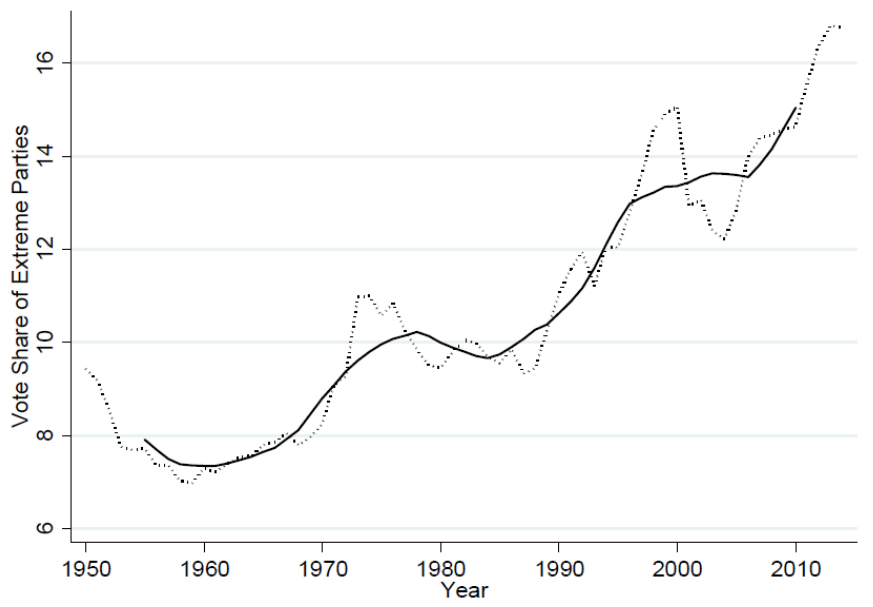

Percent of the popular vote for extreme parties on the far right or the far left for the most recent election in the lower legislature is from Funke, Schularick, and Trebesch (2016). The sample represents a balanced panel of advanced economies from Figure 3 with available vote share data (see text for more details). The dotted line represents the advanced economy average for each observation year. The solid line is the 10 -year moving average. 
Figure 8. Rising Political Fractionalization in Advanced Economies

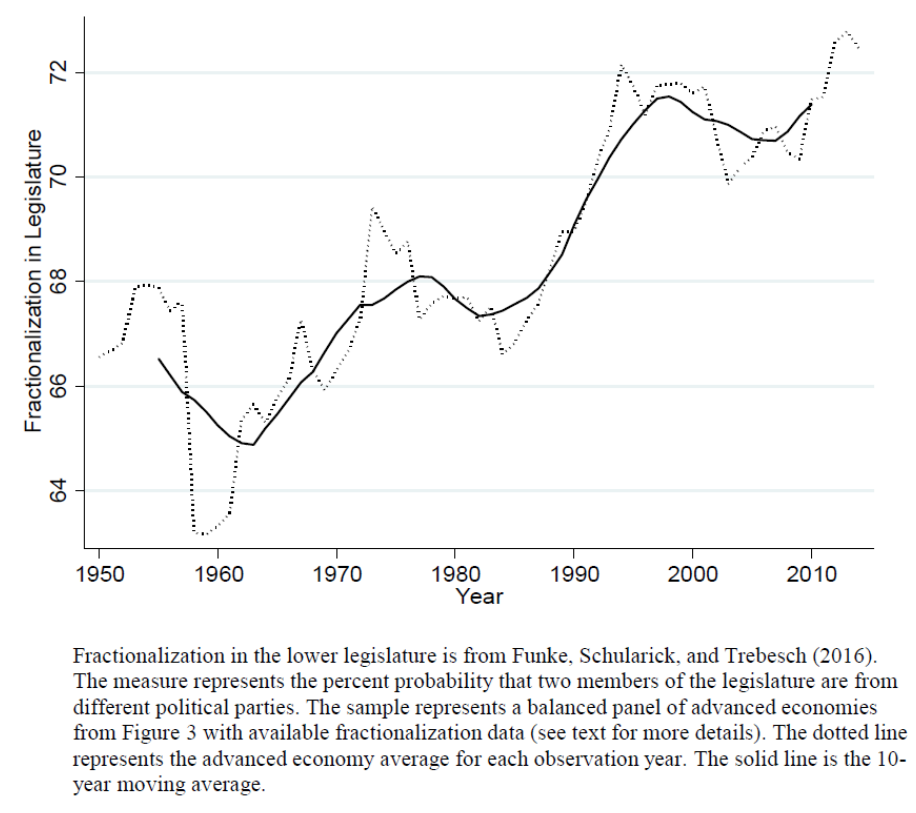

\subsection{Political Turnover}

A large literature focuses on the third explanation for rising government debt: political turnover. ${ }^{54}$ In contrast to the tragedy of the commons, the present bias in policymaking is not due to a lack of (intratemporal) coordination. Instead, present bias results from the interaction of two factors: the temporary concentration of political authority in one political party, which benefits disproportionately from current spending, and the inability of parties to make binding (intertemporal) commitments to one another.

We can illustrate this idea with an example from the analysis of Aguiar and Amador (2011). Suppose that there are $N$ symmetric parties, each with a rate of time preference $\delta$. For simplicity, suppose that only one party has the authority to make fiscal policy decisions at any date. When a party is out of power, it puts a weight of 1 on the value of government spending, whereas when it is in power, it puts a weight of $\theta>1$ on the value of spending. The parameter $\theta$ captures the degree to which a party can derive additional benefits from spending while in power by boosting its popularity, concentrating spending on preferred initiatives, or increasing wasteful rents. The probability of any given party

\footnotetext{
${ }^{54}$ For example, see Persson and Svensson (1989), Alesina and Tabellini (1990), Tabellini and Alesina (1990), Lizzeri (1999), Battaglini and Coate (2008), Caballero and Yared (2010), Yared (2010), Bouton, Lizzeri, and Persico (2016), and Müller, Storesletten, and Zilibotti (2016), among others.
} 
having power at a given date is $q=1 / N$, which captures the degree of political risk for the incumbent party. When choosing policy at date $t$, an incumbent considers the probability of holding power in the future and hence weighs periods $\{t, t+1, t+2, \ldots\}$ according to (effective) discount rates $\left\{\theta,(q \theta+(1-q)) \delta,(q \theta+(1-q)) \delta^{2}, \ldots\right\}$. This formulation is mathematically equivalent to the quasi-hyberbolic case described at the beginning of this section, with a rate of time preference $\delta$ and deficit bias $\beta=(q \theta+(1-q)) / \theta$.

Conceptually, the presence of political turnover causes the current government to be impatient, since the party holding power recognizes that it may not have the opportunity to benefit from spending in the future. ${ }^{55}$ This present bias is more severe ( $\beta$ is lower) if the temporary benefits from spending and rent-seeking while in office are large ( $\theta$ is high), if there are more parties competing for power ( $N$ is high), or if there is more political risk ( $q$ is low). ${ }^{56}$ In addition to this present bias, government preferences are dynamically inconsistent; the party presently in power would prefer that future governments be fiscally responsible, but future governments cannot commit ex ante to future policy. In this sense, the combination of lack of commitment together with political risk causes the government to be present-biased and time-inconsistent.

This theory predicts that countries with more rent-seeking, political fragmentation, or political risk will incur larger government deficits, resulting in faster government debt accumulation. These predictions are in line with empirical cross-country studies on the determinants of government deficits. ${ }^{57}$

This theory can explain the long-term trend in government debt in advanced economies as a result of rising political uncertainty for parties in power. Figure 9 shows that the margin of victory in U.S. presidential elections has been in decline since the mid-1980s, suggesting that elections have become closer and less predictable. This pattern is in line with the analysis of U.S. congressional elections, which has documented a declining incumbency advantage since the mid-1980s (e.g., Jacobson, 2015). Moreover, this U.S. trend is consistent with the evidence from advanced economies in Figure 10, which displays a decline in the average popular vote margin in legislative elections for the governing party

\footnotetext{
${ }^{55}$ In this example, turnover is exogenous and probabilistic. However, the literature highlighted in Footnote 54 shows that the insight holds more generally if turnover is deterministic or if it is endogenous (and potentially off the equilibrium path). In addition, Persson and Svensson (1989) and Müller, Storesletten, and Zilibotti (2016) argue that the present bias may be more severe if the current party in power leans to the right and puts higher relative weight on tax cuts versus government spending increases.

${ }^{56}$ Note that if a subset of parties can make decisions at any time (e.g., Battaglini and Coate, 2008), then the number of parties and the degree of political risk are not mechanically related, as in this example.

${ }^{57}$ In addition to the work cited in Footnote 51, see Drazen (2000) and Alt and Lassen (2016) who discuss the effect of elections on deficits.
} 
or coalition..$^{58}$

Figure 9. Declining Margin of Victory in Presidential Elections in the U.S.

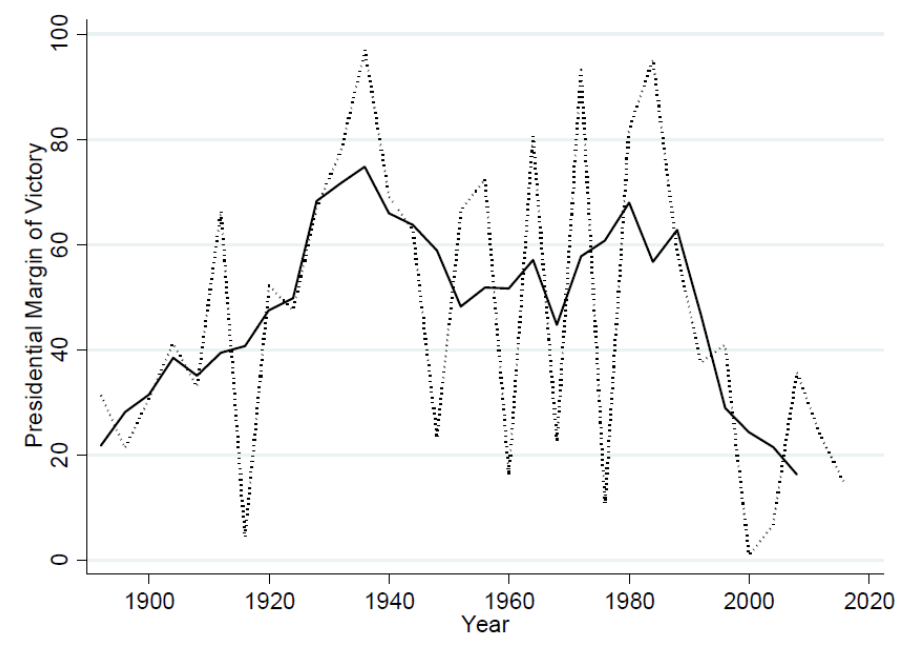

Electoral margin of victory for presidential elections is from U.S. Electoral College. The measure is the difference in electoral votes received by the winner and the runner-up as a percentage of the sum of votes received by the winner and the runner-up. The dotted line is the election year observation. The solid line is the 3 -election-year moving average.

Figure 10. Declining Margin of Victory in Legislative Elections in Advanced Economies

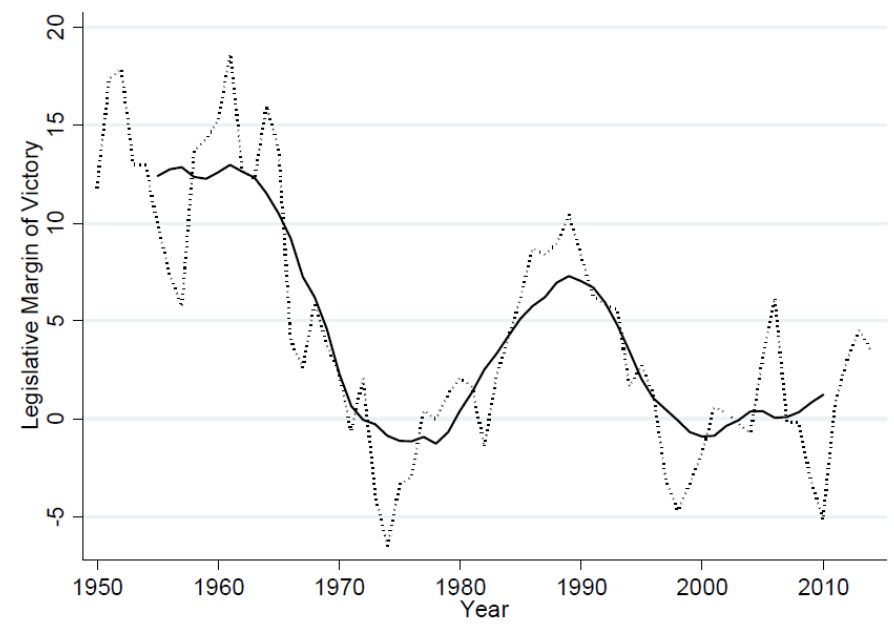

Margin of victory for the most recent election in the lower legislature is from Funke,

Schularick, and Trebesch (2016). The margin is the difference in popular votes received by the legislators in the governing party or governing coalition and the votes received by those in the opposition party or coalition as a percentage of the sum of votes received by the two groups. The sample represents a balanced panel of advanced economies from Figure 3 with available margin of victory data (see text for more details). The dotted line represents the advanced economy average for each observation year. The solid line is the 10 -year moving average.

\footnotetext{
${ }^{58}$ See Footnote 53 for additional information on the sample.
} 


\subsection{Assessment}

In contrast with normative theories, political economy theories of government debt can qualitatively explain the long-term trend in government debt accumulation across advanced economies. Nevertheless, these theories leave several unanswered questions for future research.

First, it is unclear whether political economy models can quantitatively match the time-series and cross-sectional patterns in advanced economy government debt. Many normative models of government debt have been evaluated quantitatively, sometimes with counterfactual conclusions regarding the size and structure of government debt. ${ }^{59}$ An analogous analysis of political economy models could potentially clarify what political factors can best account for the upward trend in government debt. Second, while political economy theories explain why an increase in polarization and electoral uncertainty can lead to rising debt, they do not explain why polarization and electoral uncertainty have increased in advanced economies, and how this development may have been caused by certain economic trends or policies. ${ }^{60}$ Finally, current political economy theories do not directly address the change in the composition of government spending, which has become increasingly concentrated in old-age government assistance programs. This development could reflect how different political forces interact in the world, as increasingly competititve political parties change the composition of government spending and increase government debt to appeal to an aging constituency. ${ }^{61}$

\section{Fiscal Rules to Constrain Rising Debt}

A resonating theme across every political explanation for rising debt discussed in the previous section is the time-inconsistency in government preferences. Current governments want to be fiscally irresponsible, while simultaneously hoping that future governments be fiscally responsible. This force explains why governments across the world have been compelled to adopt fiscal rules — such as mandated deficit, spending, or revenue limits - to

\footnotetext{
${ }^{59}$ For example, in their evaluation of the tax-smoothing model under incomplete markets, Aiyagari, et al. (2002) and Bhandari, et al. (2017a) find that the optimal level of government debt is negative. Angeletos (2002) and Buera and Nicolini (2004) evaluate the tax-smoothing model under complete markets and find that debt positions at different maturities can take opposite signs and be extremely large (in absolute value) relative to GDP.

${ }^{60} \mathrm{McCarty}$, Poole, and Rosenthal (2008), for example, argue that polarization and income inequality reinforce each other.

${ }^{61}$ An additional question regards how the political factors behind present bias, such as polarization, interact with asymmetric information across political parties. Alesina and Drazen (1991) argue that fiscal stabilizations can be delayed when a one party is uncertain about the rival party's cost of high debt.
} 
restrict future fiscal policy and curtail the increase in government debt. Figure 11 illustrates the growing number of countries that have imposed fiscal rules. ${ }^{62}$ These rules have been adopted at the subnational, national, and supranational levels. In some countries, such as in Switzerland, they have been an effective force at limiting the government's deficit bias and curbing the increase in debt, as Figure 12 makes clear. ${ }^{63}$

Given their prevalence, an important question concerns the optimal structure of fiscal rules, as well as the practical challenges in implementing them. In this section, I describe recent research on the optimal design of fiscal rules, elucidating the fundamental tradeoff between commitment and flexibility underpinning these rules. I address what this tradeoff implies for various features of fiscal rules in theory and in practice. This discussion touches on how rules should be conditioned on public information, how they should be enforced, how they should be applied at a supranational level, whether they should feature escape clauses, and whether they should be based on fiscal policy tools or targets.

Figure 11. Number of Countries with Fiscal Rules

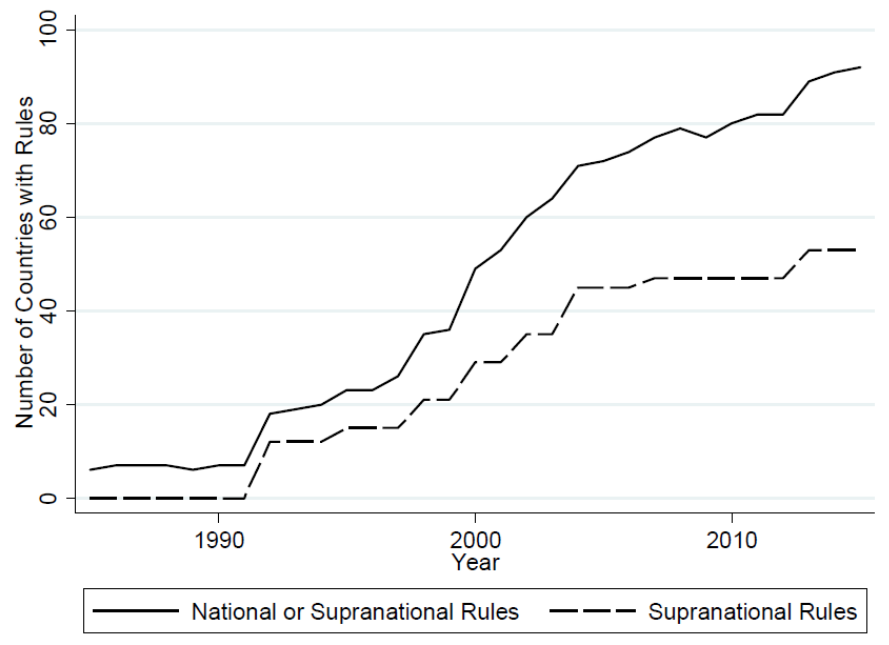

Data is from International Monetary Fund. A country is classified as having a fiscal rule if it is subject to an expenditure rule, a revenue rule, a budget balance rule, or a debt rule.

\footnotetext{
${ }^{62}$ For a complete description of the fiscal rule adopted in each country, see Lledó, et al. (2017). The U.S. is currently subject to spending caps passed in the Budget Control Act of 2011 which were subsequently increased by Congress in 2013, 2015, and 2018. A criticism of these spending caps is that they do not apply to most mandatory spending items underlying the growth in debt (see Capretta, 2014).

${ }^{63}$ See Salvi, Schaltegger, and Schmid (2017) for an analysis of the case of Switzerland and Wyplosz (2014) and Caselli et al. (2018) for a broader discussion of the effectiveness of national and supranational rules at reducing debt. See Poterba (1994, 1996), Bohn and Inman (1996), Fatás and Mihov (2006), and Primo (2007) for an analysis of the effectiveness of subnational rules in the U.S. See Grembi, Nannicini, and Troiano (2016) for a related subnational analysis for the case of Italy.
} 
Figure 12. Adoption of Fiscal Rule in Switzerland

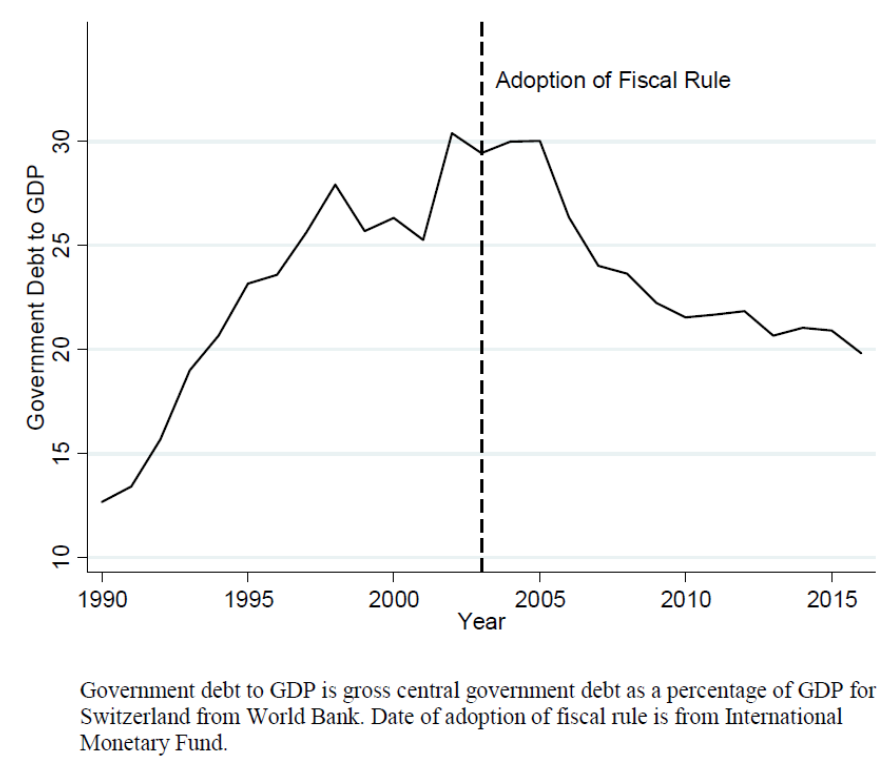

\subsection{Commitment vs. Flexibility}

In practice, tight fiscal rules that successfully limit debt accumulation are associated with a less responsive and less volatile fiscal policy. ${ }^{64}$ This observation reflects the fundamental tradeoff between commitment and flexibility underlying fiscal rules. On the one hand, rules provide valuable commitment, as they can counteract the present bias in policymaking; on the other hand, there is a cost of reduced flexibility as fiscal constitutions cannot spell out policy prescriptions for every single shock or contingency, and some discretion may be optimal. ${ }^{65}$

There are two approaches to the theoretical analysis of this tradeoff. The first approach restricts the structure of a fiscal rule to a form used in practice - such as a deficit limitand evaluates the stringency of an optimal rule (e.g., Azzimonti, Battaglini, and Coate, 2016, Halac and Yared, 2018a). ${ }^{66}$ The second approach does not restrict the structure of a fiscal rule and uses mechanism design to simultaneously characterize the structure and the stringency of an optimal rule (e.g., Amador, Werning, and Angeletos, 2006, and Halac and Yared, 2014, 2016, 2017, 2018b). This second approach distinguishes between fiscally relevant information on which a fiscal rule can explicitly depend-such as the

\footnotetext{
${ }^{64}$ See, for example, the work cited in Footnote 63.

${ }^{65} \mathrm{~A}$ related commitment-versus-flexibility tradeoff arises in the institution of monetary rules. See for example the discussion in Rogoff (1983), Lohmann (1992), and Athey, Atkeson, and Kehoe (2006), among others.

${ }^{66}$ Additional examples of this approach include Coate and Milton (2017), Alfaro and Kanczuk (2016), and Dovis and Kirpalani (2017), among others.
} 
level of public debt or GDP - and fiscally relevant information on which a fiscal rule cannot explicitly depend - such as the depth of a financial crisis or the wartime needs of the military. This latter type of information can be thought of as the government's private information, since it is payoff relevant but cannot be part of a rule's description. ${ }^{67}$ An optimal fiscal rule then is represented as a policy prescription that maximizes social welfare subject to the government's private information and present bias. ${ }^{68}$

The advantage of the first approach is that it can be used to assess real world rules and evaluate the costs and benefits of partial reform in a framework that incorporates a rich set of macroeconomic and political forces. The advantage of the second approach is that it can be used to ask whether the overall structure of real world rules is optimal and to evaluate the costs and benefits of global - as opposed to partial-reform. This second approach also elucidates how other considerations, on top of private information and present bias, may contribute to the determination of an optimal rule, which can often take a simple, realistic form. These two approaches complement each other and provide useful lessons for the optimal design of fiscal rules. ${ }^{69}$

In the next subsections, I discuss what the tradeoff between commitment and flexibility implies for various features of fiscal rules in theory and in practice.

\subsection{Conditioning on Information}

An optimal fiscal rule conditions on fiscally relevant information that is observable and verifiable, such as the level of debt and GDP. If no additional (private) information informs optimal fiscal policy, the rule would take the form of a contingent policy prescription that affords no discretion to policymakers. In practice, however, not all fiscally relevant information can be easily observed and verified, and some discretion may be beneficial. A commitment-versus-flexibility tradeoff then arises, as discretion comes at the cost of

\footnotetext{
${ }^{67}$ Formally, this private information may be publicly observable but not verifiable by a rule-making body. An alternative interpretation of the private information is that it represents the aggregation of individual citizens' preferences observable only to the government (e.g., Sleet 2004, Piguillem and Schneider, 2016). Another interpretation is that the private information corresponds to fiscally relevant data - such as the exact cost of public goods - which is only known to the government.

${ }^{68}$ This approach is related to the study of delegation in principal-agent settings, including Holmström (1977, 1984), Melumad and Shibano (1991), Alsonso and Matouschek (2008), Amador and Bagwell (2013), and Ambrus and Egorov $(2013,2017)$, among others. The delegation problem concerns a principal who provides incentives to a better informed but biased agent by limiting the agent's actions (since transfers are infeasible). In contrast to the analysis of delegation, the analysis of fiscal rules must address the dynamic inconsistency in the agent's (the government's) preferences.

${ }^{69}$ The difference between these two approaches is analogous to that between the Ramsey and Mirrlees approaches to optimal taxation. See Mankiw, Weinzerl, and Yagan (2009) for a discussion of this distinction.
} 
excessive borrowing due to the government's present bias. Amador, Werning, and Angeletos (2006) show that, under some conditions, the optimal resolution of this tradeoff is a threshold rule, taking the form of a deficit, spending, or revenue limit, as is often observed in practice. ${ }^{70}$ The optimal threshold is tighter the smaller is the volatility of the government's private information and the more severe is the government's present bias, as in both cases the value of commitment is increased relative to the value of flexibility.

There are important challenges in determining how to optimally set fiscal thresholds. First, there are practical questions regarding implementation. Recent research has been devoted to examining which macroeconomic measures should be used to set a threshold, how to weigh the relative importance of these measures, and how to set the numerical targets so as to afford sufficient flexibility while simultaneously preventing excessive debt growth. ${ }^{71}$ Second, when some fiscally relevant information is not verifiable, there are conceptual questions regarding what other information an optimal fiscal rule should condition on. In particular, Halac and Yared (2014) show that if the government's private information is persistent over time, an optimal fiscal rule should condition on the extent to which past policies agreed with fiscal targets, even if this measure is irrelevant for optimal policy determination. How to practically incorporate these considerations into real world fiscal rules is an interesting area for future research.

\subsection{Enforcement}

According to the International Monetary Fund, governments comply with fiscal rules only about 50 percent of the time. ${ }^{72}$ Whenever a rule is violated, a formal or informal enforcement mechanism is triggered. For example, in the European Union, an Excessive Deficit Procedure - a sequence of costly fiscal adjustments and potential sanctions - is set in motion whenever a rule is breached. ${ }^{73}$ In contrast, in Chile, there are no formal procedures, and penalties for rule violation have been informal. In 2009, a breach of the fiscal rule by the Chilean administration was informally punished by the next administration, which

\footnotetext{
${ }^{70}$ This result requires certain assumptions on the distribution of private information and the government's preferences. Without these assumptions, an optimal rule is more complex and can involve multiple policy thresholds.

${ }^{71}$ As an example, Azzimonti, Battaglini, and Coate (2016) analyze the short- and long-term costs and benefits of adopting a balanced budget amendment in the U.S. Alfaro and Kanczuk (2016) compare the performance of a debt-independent deficit limit to a pure debt limit for the case of Brazil. Hatchondo, Martinez, and Roch (2017) argue that fiscal rules should not be absolute and should respond flexibly to market signals such as sovereign spreads. See Eyraud, Baum, et al. (2018) for a general discussion of the challenges in calibrating fiscal rules.

${ }^{72}$ See Caselli et al. (2018).

${ }^{73}$ See Lledó, et al. (2017, p.81) for a description of this procedure.
} 
continued to ignore the rule despite criticism of fiscal irresponsibility. ${ }^{74}$ This example highlights a self-enforcement mechanism: the threat of rule abandonment by future governments may serve as a deterrent for a current government considering breaking a fiscal rule.

How should fiscal rules be structured under limited enforcement? Halac and Yared (2017) address this question in a commitment-versus-flexibility framework with limited punishments that harm both the government and society. They show that under some conditions, the optimal rule is a maximally-enforced threshold, namely a deficit, spending, or revenue limit that triggers the largest feasible penalty whenever violated. A key insight is that, even though graduated punishments are less socially costly ex post, they are suboptimal ex ante as they induce too little fiscal discipline. ${ }^{75}$ Furthermore, this analysis shows that fiscal thresholds that are never violated by the government may be too lax and thus also suboptimal. This occurs when the government's present bias is severe and situations of extreme fiscal need are rare. The fiscal rule should then be tight enough as to be occasionally broken, since the social cost of infrequent punishment is outweighed by the benefit of increased fiscal discipline in normal times.

There are several issues to take into account when considering punishments for breaking fiscal rules. First, whether or not rules have been broken might be unclear due to lack of transparency. Governments can utilize creative accounting techniques to circumvent rules. For example, in 2016, President Dilma Rousseff of Brazil was impeached for illegally using state-run banks to directly pay for government expenses and bypass the fiscal responsibility law. ${ }^{76}$ Given this problem of transparency, many countries have established independent fiscal councils to assess and monitor the implementation of fiscal policy together with the compliance with fiscal rules. ${ }^{77}$

A second issue to consider is credibility. Non-credible punishments are ineffective to enforce fiscal rules. As an example, the Excessive Deficit Procedure against France and Germany in 2003 was stalled because of disagreement between the European Commission and the European Council; consequently, French and German deficits persisted without

\footnotetext{
${ }^{74}$ See Halac and Yared (2017) for a description of this episode.

${ }^{75}$ This insight relies on a technical result that incentives take a bang-bang form. In the model of Halac and Yared (2017), this high-powered incentive structure is optimal since rewards and punishments are experienced jointly by the government and society.

${ }^{76}$ See Leahy (2016) for a discussion. Another form of liability shifting in U.S. states has involved compensating government employees with future pension payments, which increases off-balance-sheet entitlement liabilities not subject to fiscal rules (see Bouton, Lizzeri, and Persico, 2016). Frankel and Schreger (2013) describe another example of creative accounting in the Euro area. They argue that governments utilize over-optimistic growth forecasts as a means of minimizing the burden of complying with fiscal rules.

${ }^{77}$ See Debrun et al. (2013) for an overview of these institutions.
} 
penalty. ${ }^{78}$ Halac and Yared (2017) argue that in the absence of institutionalized penalties, the temporary abandonment of rules combined with overspending - as in the Chilean case previously described - can serve as its own deterrent for breaking a fiscal rule. Such an informal punishment is arguably easier to enforce than formal sanctions, as there is typically some constituency in favor of increasing spending. ${ }^{79}$

A final issue to consider is the response of the private sector to a violation of rules, which can also serve as a form of punishment. For example, Caselli et al. (2018) find that the violation of fiscal rules is associated with a significant increase in sovereign spreads. Such an increase in financing costs immediately penalizes a government for breaching a rule. $^{80}$

\subsection{Coordinated Rules}

More than half of the countries subject to fiscal rules face rules that apply at a supranational level. Moreover, among these countries, more than a dozen have additional rules at the national level. ${ }^{81}$ For example, Germany is constrained not only by the guidelines of the European Union's Stability and Growth Pact (SGP), but also by its own constitutionally mandated "debt brake", which imposes a tighter limit on the government's structural deficit than the SGP. ${ }^{82}$

The main argument for imposing rules at a supranational level relates to the tragedy of the commons. Individual countries in an integrated economic region do not internalize the impact of their borrowing decisions on the shared interest rates, inflation rates, or probability of financial contagion. Supranational fiscal rules can limit this externality. ${ }^{83}$

The adoption of supranational rules comes with numerous challenges. First, the imposition of uniform thresholds for multiple countries under a supranational rule, as in the case of the SGP, may be inappropriate if countries are likely to differ in the level or

\footnotetext{
${ }^{78}$ See Tran (2003) for a discussion.

${ }^{79} \mathrm{~A}$ similar mechanism underlies the incentive benefit of formal institutions that make current spending increases automatically persist into the future (e.g., Bowen, Chen, and Eraslan, 2014, and Piguillem and Riboni, 2018).

${ }^{80}$ This idea can be formalized in a model of government debt and default which features multiple equilibria resulting from self-fulfilling market expectations (e.g., Calvo, 1988).

${ }^{81}$ The treaties that encompass the supranational rules correspond to the European Union's Stability and Growth Pact, the West African Economic and Monetary Union, the Central African Economic and Monetary Community, and the Eastern Caribbean Currency Union. The countries with both national and supranational rules are all in the European Union.

${ }^{82}$ See Truger and Will (2013).

${ }^{83}$ Halac and Yared (2018a) discuss the role of fiscal rules in the context of shared interest rates. Beetsma and Uhlig (1999), Chari and Kehoe (2007), and Aguiar et al. (2015) discuss them in the context of shared inflation rates.
} 
volatility of their fiscal needs or in the severity of their governments' present bias. Hatchondo, Martinez, and Roch (2017) argue that conditioning thresholds on market signals, like a sovereign interest spread, allows supranational rules to more effectively tailor to individual countries.

Second, the design of rules at a supranational level must account for the disciplining effect of interest rates (Halac and Yared, 2018a). Excessively tight supranational rules not only reduce flexibility, but they promote fiscal irresponsibility by reducing regional interest rates and governments' cost of funding. ${ }^{84}$ In addition, countries that complement supranational rules with more stringent rules at the national level - as in the case of Germany in the European Union - exert an externality by driving down regional interest rates and reducing fiscal discipline in other countries. Halac and Yared (2018a) show that in the face of such low interest rates, supranational rules must be made more stringent. ${ }^{85}$

Finally, whether supranational rules are easier or harder to enforce than national rules is an open theoretical and empirical question. On the one hand, supranational rules may be easier to enforce since the international economic system provides more tools for sanctioning, and the supranational sanctioning authority may be less subject to domestic political pressures. On the other hand, there is a collective action problem in the enforcement of supranational rules. Moreover, disagreement may be another impediment, as in the case described previously concerning the enforcement of the European Union's Excessive Deficit Procedure in 2003.

\subsection{Escape Clauses}

Many fiscal rules feature an escape clause to allow the government to violate the rule under exceptional circumstances. Triggering an escape clause typically involves a costly review process, which culminates in a final decision by an independent fiscal council, a legislature, or citizens via a referendum. In Switzerland, for example, the government can deviate from a fiscal rule with a legislative supermajority in the cases of natural disaster, severe recession, or changes in accounting method. ${ }^{86}$

\footnotetext{
${ }^{84}$ Fernández-Villaverde, Garicano, and Santos (2013) argue that the drop in interest rates that followed European integration led to the abandonment of reforms and institutional deterioration in the peripheral European countries.

${ }^{85}$ This is because the ensuing international imbalances amplify the interest rate externality due to the tragedy of the commons. Halac and Yared (2018a) also show that if the disciplining effect of interest rates is strong enough, supranational surplus limits which increase interest rates are optimal. This theoretical consideration can justify initiatives like the Macroeconomic Imbalance Procedure in the European Union, which limits current account surpluses (indirectly tied to budget surpluses) to 6 percent of GDP (see European Commission, 2016, Table 3.2).

${ }^{86}$ See Lledó, et al. (2017) for examples of countries with escape clause mechanisms.
} 
Escape clauses function somewhat like the enforcement mechanisms described previously, since triggering them is costly and this deters governments from using them too frequently. However, in contrast to enforcement mechanisms, the costs here are directly related to the resources required for evaluation and deliberation. Moreover, since escape clauses facilitate information gathering to promote efficient fiscal policy, they are useful even in the presence of perfect rule enforcement.

Coate and Milton (2017) and Halac and Yared (2016) study fiscal rules that make use of escape clauses in a commitment-versus-flexibility framework. ${ }^{87}$ They find that introducing escape clause provisions is optimal if (privately observed) fiscal shocks are sufficiently volatile, the government's present bias is sufficiently severe, and the resource cost of triggering an escape clause is sufficiently low. In such a situation, a rule with an escape clause dominates a pure threshold rule by allowing for more flexibility in response to extreme economic conditions.

In practice, the use of escape clause provisions can be challenging. The interpretation of events in which escape clauses can be triggered is subjective, and the political deliberation surrounding an appropriate fiscal response can be uncertain and induce delay. ${ }^{88}$ Whether these costs can outweigh the benefits of using escape clauses is an open empirical question.

\subsection{Instrument-Based and Target-Based Rules}

How should fiscal rules be applied? Should the government face constraints directly on instruments of policy, such as spending, or should the fiscal rule concern targets of policy, such as deficits? And which instruments and targets are the optimal ones to be addressed?

In practice, fiscal rules can constrain different instruments of policy, such as government spending or tax rates, and can address specific categories of these instruments. For example, many countries have "golden rules", which limit spending net of a government's capital expenditure. Different instruments may call for different thresholds, as the associated commitment-versus-flexibility tradeoff may not be the same. ${ }^{89}$ For instance, due to

\footnotetext{
${ }^{87}$ Coate and Milton (2017) restrict attention to deficit limits and model escape clauses as ex-post bargaining between a government and citizens. Halac and Yared (2016) do not impose an exogenous structure on fiscal rules and model escape clauses as costly verification of the government's private information.

${ }^{88}$ See Primo $(2007,2010)$ for a discussion of the problems in implementing escape clauses in the fiscal rules of U.S. states.

${ }^{89}$ See Galperti (2018) for a theoretical exposition of this argument in the context of personal budgeting. In addition, having multiple layers of rules - for example on individual categories of spending and on overall spending - is optimal, particularly if there are complementarities from applying different fiscal instruments. This reasoning can explain why a (forecasted) deficit rule on top of a spending and tax rate
} 
volatile geopolitical conditions, military spending needs may be less forecastable ex ante than other spending needs, and may thus demand more flexibility. Capital spending is another category where allowing increased flexibility may be optimal, as the benefits of capital spending accrue well into the future and are thus subject to a less severe present bias. The evidence suggests that rules that distinguish across categories have indeed positive effects on fiscal and macroeconomic outcomes. ${ }^{90}$

Similar principles apply to the analysis of target-based rules, which specify targets for outcomes of policy, such as the deficit to GDP ratio. Target-based rules differ from instrument-based rules in two respects. ${ }^{91}$ First, a target-based rule more directly ties a government's incentives to economic goals, while giving the government greater instrument discretion to respond to changing macroeconomic conditions. Second, given the risk of macroeconomic surprises, a government may be penalized for rule breach despite its best efforts to choose instruments to satisfy the target. Therefore, an optimal target threshold should be tight enough that it induces the government to rein in its present bias through its choice of instruments, but not so tight that it is excessively prone to violations due to macroeconomic surprises.

Halac and Yared (2018b) develop a theoretical framework to compare these different classes of rules. They show that target-based rules dominate instrument-based rules if the government is sufficiently well informed, so that instrument discretion is beneficial and punishment due to macroeconomic surprises is relatively unlikely. Bohn and Inman (1996) analyze fiscal rules of U.S. states and find that target-based rules, in the form of end-of-the-year fiscal requirements, perform better than instrument-based rules, in the form of beginning-of-the-year fiscal requirements. Finally, Halac and Yared (2018b) show theoretically how a simple hybrid rule - which allows for an instrument threshold that is relaxed whenever a target threshold is satisfied - would do better than either class.

\section{Concluding Remarks}

Over the past four decades, government debt as a fraction of GDP has been on an upward trajectory in advanced economies, approaching levels not reached since World War II. While normative macroeconomic theories can explain the increase in the level of debt

\footnotetext{
rule can be optimal.

${ }^{90}$ Bassetto and Sargent (2006) address the benefits of a "golden rule" in a calibrated theoretical model, and Poterba (1995) assesses the rule's impact in the context of U.S. states. See Eyraud, Lledó, et al. (2018) for an additional discussion of issues to consider in rule selection.

${ }^{91}$ Halac and Yared (2018b) formalize these different rule classes in an extended delegation framework that incorporates a noisy observable outcome.
} 
in certain periods as a response to macroeconomic shocks, they cannot explain the broadbased long-run trend in debt accumulation. In contrast, political economy theories can explain the long-run trend as resulting from an aging population, rising political polarization, and rising electoral uncertainty across advanced economies.

Political economy theories emphasize the time-inconsistency in government policymaking, and thus the need for fiscal rules that restrict policymakers. Many countries have adopted fiscal rules to rein in growing debts. Most of these rules were recently introduced, and time will tell whether they lead to sustainable government finances and to a reversal of a decades-old trend. Their success depends, in part, on whether they appropriately balance the tradeoff between commitment and flexibility underpinning these rules, and whether they address other challenges that I have highlighted, such as enforceability.

This discussion leaves us with several interesting questions for future research. First, while I have focused on fiscal rules as a solution to growing debts, in practice, the introduction of fiscal rules should be combined with additional reforms to budgetary procedures. How specific procedural rules, such as voting or amendment rules, complement or thwart the effect of fiscal rules is an important issue to consider. ${ }^{92}$ Second, a government's deficit bias is not constant, since it evolves over time in response to factors such as changing polarization and electoral uncertainty. Understanding how these underlying political forces are impacted by fiscal policy and by the introduction of fiscal rules is important for governments contemplating rule adoption. Finally, the introduction and implementation of fiscal rules requires a level of political consensus and stability, which is likely to emerge during a period of responsible policymaking, when the benefit of rules is less salient. How to take advantage of such an occasion to adopt and improve fiscal rules, rather than letting it pass as a missed opportunity, is critical for limiting the growth of government debt.

\footnotetext{
${ }^{92}$ Capretta (2014), for example, suggests reforms to the U.S. budget process that would allow Congress to more easily change entitlement policy.
} 


\section{References}

Abel, Andrew B., N. Gregory Mankiw, Lawrence H. Summers, and Richard J. Zeckhauser. 1989. "Assessing Dynamic Efficiency: Theory and Evidence." Review of Economic Studies, 56: 1-20.

Aguiar, Mark, and Manuel Amador. 2011. "Growth in the Shadow of Expropriation." Quarterly Journal of Economics, 126(2): 651-697.

Aguiar, Mark, Manuel Amador, Emmanuel Farhi, and Gita Gopinath. 2015. "Coordination and Crisis in Monetary Unions." Quarterly Journal of Economics, 130(4): 1727-1779.

Aiyagari, Rao S., Albert Marcet, Thomas J. Sargent, and Juha Seppälä. 2002. "Optimal Taxation without State-Contingent Debt." Journal of Political Economy, 110(6): 1220-1254.

Aiyagari, Rao S., and Ellen R. McGrattan. 1998. "The Optimum Quantity of Debt." Journal of Monetary Economics, 42(3): 447-469.

Ales, Laurence, Pricila Maziero, and Pierre Yared. 2014. "A Theory of Political and Economic Cycles." Journal of Economic Theory, 153: 224-251.

Alesina, Alberto. 2000. "The Political Economy of the Budget Surplus in the United States." Journal of Economic Perspectives, 14(3): 3-19.

Alesina, Aberto, and Allan Drazen. 1991. "Why Are Stabilizations Delayed?" American Economic Review, 81(5): 1170-1188.

Alesina, Alberto, and Andrea Passalacqua. 2016. "The Political Economy of Government Debt." In Handbook of Macroeconomics, 2, 2599-2651. Amsterdam: Elsevier.

Alesina, Alberto, and Guido Tabellini. 1990. "A Positive Theory of Fiscal Deficits and Government Debt." Review of Economic Studies, 57: 403-414.

Alfaro, Laura, and Fabio Kanczuk. 2016. "Fiscal Rules and Sovereign Default." NBER Working Paper 23370.

Alonso, Ricardo, and Niko Matouschek. 2008. "Optimal Delegation." Review of Economic Studies, 75(1): 259-293.

Alt, James E., and David Dreyer Lassen. 2006. "Transparency, Political Polarization, and Political Budget Cycles in OECD Countries." American Journal of Political Science, 50(3): 530-550.

Amador, Manuel, and Kyle Bagwell. 2013. "The Theory of Optimal Delegation with an Application to Tariff Caps." Econometrica, 81(4): 1541-1599.

Amador, Manuel, Iván Werning, and George-Marios Angeletos. 2006. "Commitment vs. Flexibility." Econometrica, 74(2): 365-396. 
Ambrus, Attila, and Georgy Egorov. 2013. "Comment on "Commitment vs. Flexibility"." Econometrica, 81(5): 2113-2124.

Ambrus, Attila, and Georgy Egorov. 2017. "Delegation and Nonmonetary Incentives." Journal of Economic Theory, 171: 101-135.

Angeletos, George-Marios. 2002. "Fiscal Policy with Noncontingent Debt and the Optimal Maturity Structure." Quarterly Journal of Economics, 117(3): 1105-1131.

Angeletos, George-Marios, Fabrice Collard, and Harris Dellas. 2016. "Public Debt as Private Liquidity: Optimal Policy." NBER Working Paper 22794.

Athey, Susan, Andrew Atkeson, and Patrick J. Kehoe. 2005. "The Optimal Degree of Discretion in Monetary Policy." Econometrica, 73(5): 1431-1475.

Azzimonti, Marina. 2018. "Partisan Conflict and Private Investment." Journal of Monetary Economics, 93: 114-131.

Azzimonti, Marina, Marco Battaglini, and Stephen Coate. 2016. "The Costs and Benefits of Balanced Budget Rules: Lessons from a Political Economy Model of Fiscal Policy." Journal of Public Economics, 136: 45-61.

Azzimonti, Marina, Eva de Francisco, and Vincenzo Quadrini. 2014. "Financial Globalization, Inequality, and the Rising Public Debt." American Economic Review, 104(8): 2267-2302.

Azzimonti, Marina, and Pierre Yared. 2017. "A Note on Optimal Fiscal Policy in an Economy with Private Borrowing Limits." Economics Letters, 151: 62-65.

Azzimonti, Marina, and Pierre Yared. 2018. "The Optimal Public and Private Provision of Safe Assets." NBER Working Paper 24534.

Barro, Robert J. 1974. "Are Government Bonds Net Wealth?" Journal of Political Economy, 82(6): 1095-1117.

Barro, Robert J. 1979. "On the Determination of the Public Debt." Journal of Political Economy, 87(5): 940-971.

Bassetto Marco, and Thomas J. Sargent. 2006. "Politics and Efficiency of Separating Capital and Ordinary Government Budgets." Quarterly Journal of Economics, 121(4): 1167-1210.

Battaglini, Marco, and Stephen Coate. 2008. "A Dynamic Theory of Public Spending, Taxation, and Debt." American Economic Review, 98(1): 201-236.

Battaglini, Marco, and Stephen Coate. 2016. "A Political Economy Theory of Fiscal Policy and Unemployment." Journal of the European Economic Association, 14(2): 303-337.

Beetsma, Roel, and Harald Uhlig. 1999. "An Analysis of the Stability and Growth Pact." Economic Journal, 109: 546-571. 
Bernanke, Ben S. 2005. "The Global Saving Glut and the U.S. Current Account Deficit." Remarks at the Sandridge Lecture, Virginia Association of Economists, March $10,2015$.

https://www.federalreserve.gov/boarddocs/speeches/2005/200503102/

Bernheim, B. Douglas, Debraj Ray, and Sevin Yeltekin. 2015. "Poverty and Self-Control." Econometrica, 83(5): 1877-1911.

Betz, Hans-Georg. 1994. Radical Right-Wing Populism in Western Europe. New York: MacMillan Press.

Bhandari, Anmol, David Evans, Mikhail Golosov, and Thomas J. Sargent. 2017a. "Fiscal Policy and Debt Management with Incomplete Markets." Quarterly Journal of Economics, 132(2): 617-663.

Bhandari, Anmol, David Evans, Mikhail Golosov, and Thomas J. Sargent. 2017b. "Public Debt in Economies with Heterogenous Agents." Journal of Monetary Economics, 91: 39-51.

Bisin, Alberto, Alessandro Lizzeri, and Leeat Yariv. 2015. "Government Policy with Time-Inconsistent Voters." American Economic Review, 105(6): 1711-37.

Blahous, Charles P. 2013. "Why We Have Federal Deficits: The Policy Decisions that Created Them." Mercatus Center Research Paper

https://www.mercatus.org/publication/why-we-have-federal-deficits-policy-decisions-createdthem

Blanchard, Olivier J. 1985. "Debt, Deficits, and Finite Horizons." Journal of Political Economy, 93(2): 223-247.

Bohn, Henning, and Robert P. Inman. 1996. "Balanced-Budget Rules and Public Deficits: Evidence from U.S. States." Carnegie-Rochester Conference Series on Public Policy, 45: 13-76.

Bohn, Henning. 1990. "Tax Smoothing with Financial Instruments." American Economic Review, 80(5): 1217-1230.

Borensztein, Eduardo, and Ugo Panizza. 2008. "The Costs of Sovereign Default." International Monetary Fund Staff Papers, 56(4): 683-741.

Boskin, Michael J., John H. Cochrane, John F. Cogan, George P. Shultz, and John B. Taylor. 2018. "A Debt Crisis is on the Horizon." Washington Post, March $27,2018$.

Bouton, Laurent, Alessandro Lizzeri, and Nicola Persico. 2016. "The Political Economy of Debt and Entitlements." NBER Working Paper 22570.

Bowen, T. Renee, Ying Chen, and Hüyla Eraslan. 2014. "Mandatory versus Discretionary Spending: The Status Quo Effect." American Economic Review, 104(10): 
2941-2974.

Brandt, Michael W., Alon Brav, John R. Graham, and Alok Kumar. 2010. "The Idiosyncratic Volatility Puzzle: Time Trend or Speculative Episodes?" Review of Financial Studies, 23(2): 863-899.

Buchanan, James M., and Richard E. Wagner. 1977. Democracy in Deficit: The Political Legacy of Lord Keynes. New York: Academic Press.

Buera, Francisco, and Juan Pablo Nicolini. 2004. "Optimal Maturity of Government Debt without State Contingent Bonds." Journal of Monetary Economics, 51: 531-554.

Caballero, Ricardo J., and Pierre Yared. 2010. "Future Rent-Seeking and Current Public Savings." Journal of International Economics, 82: 124-136.

Caballero, Ricardo J., Emmanuel Farhi, and Pierre-Olivier Gourinchas. 2017. "The Safe Assets Shortage Conundrum." Journal of Economic Perspectives, 31(3): $29-46$.

Calvo, Guillermo A. 1998. "Servicing the Public Debt: Role of Expectations." American Economic Review, 78(4): 647-661.

Calvo, Guillermo A., and Maurice Obstfeld. 1988. "Optimal Time-Consistent Fiscal Policy with Finite Lifetimes." Econometrica, 56(2): 411-432.

Campbell, John Y., Martin Lettau, Burton G. Malkiel, and Yexiao Xu. 2001. "Have Individual Stocks Become More Volatile?: An Empirical Exploration of Idiosyncratic Risk." Journal of Finance, 56(1): 1-43.

Cao, Dan, and Iván Werning. 2017. "Saving and Dissaving with Hyperbolic Discounting." Econometrica, forthcoming.

Capretta, James C. 2014. "Reforming the Budget Process." National Affairs, 21, 64-80.

Caselli, Francesca, Luc Eyraud, Andrew Hodge, Federico Diaz Kalan, Young Kim, Victor Lledó, Samba Mbaye, Adina Popescu, Wolf Heinrich Reuter, Julien Reynaud, Elif Ture, and Philippe Wingender. 2018. "Second-Generation Fiscal Rules: Balancing Simplicity, Flexibility, and Enforceability." International Monetary Fund Staff Discussion Note 18-04.

Chang, Roberto. 1990. "International Coordination of Fiscal Deficits." Journal of Monetary Economics, 25: 347-366.

Chari, V.V., Lawrence J. Christiano, and Patrick J. Kehoe. 1994. "Optimal Fiscal Policy in a Business Cycle Model." Journal of Political Economy, 102(4): 617-652.

Chari, V.V., and Patrick J. Kehoe. 1993a. "Sustainable Plans and Debt." Journal of Economic Theory, 61: 230-261. 
Chari, V.V., and Patrick J. Kehoe. 1993b. "Sustainable Plans and Mutual Default." Review of Economic Studies, 60(1): 175-195.

Chari, V.V., and Patrick J. Kehoe. 2007. "On the Need for Fiscal Constraints in a Monetary Union." Journal of Monetary Economics, 54: 2399-2408.

Chatterjee, Satyajit, and Burcu Eyigungor. 2016. "Continuous Markov Equilibria with Quasi-Geometric Discounting." Journal of Economic Theory, 163: 467-494.

Coate, Stephen, and Ross Milton. 2017. "Optimal Fiscal Limits with Overrides." Unpublished.

http://rossmilton.com/optfisclim17.pdf

Congressional Budget Office. 2017. "An Evaluation of CBO's Part Outlay Projections."

www.cbo.gov/publication/53328

Congressional Budget Office. 2018. "The Budget and Economic Outlook: 20182028."

www.cbo.gov/publication/53651

Crivelli, Ernesto, Sanjeev Gupta, Carlos Mulas-Granados, and Carolina Correa-Caro. 2016. "Fragmented Politics and Public Debt." International Monetary Fund Working Paper 16-190.

Cukierman, Alex, and Allan H. Meltzer. 1989. "A Political Theory of Government Debt and Deficits in a Neo-Ricardian Framework." American Economic Review, 79(4): 713-732.

Debortoli, Davide, Ricardo Nunes, and Pierre Yared. 2017. "Optimal TimeConsistent Government Debt Maturity." Quarterly Journal of Economics, 132(1): 55-102.

Debortoli, Davide, Ricardo Nunes, and Pierre Yared. 2018. "Optimal Taxation and Debt Management without Commitment." NBER Working Paper 24522.

Debrun, Xavier, Tidiane Kinda, Teresa Curristine, Luc Eyraud, Jason Harris, and Johann Seiwald. 2013. "The Functions and Impact of Fiscal Councils." IMF Policy Paper, July 16, 2013.

Diamond, Peter A. 1965. "National Debt in Neoclassical Growth Model." American Economic Review, 55(5): 1126-1150.

Dovis, Alessandro, and Rishabh Kirpalani. 2017. "Fiscal Rules, Bailouts, and Reputation in Federal Governments." NBER Working Paper 23942.

Drazen, Allan. 2000. "The Political Business Cycle after 25 Years." NBER Macroeconomics Annual, 15: 75-117.

Eberhardt, Markus, and Andrea F. Presbitero. 2015. "Public Debt and Growth: Heterogeneity and Non-Linearity," Journal of International Economics, 97: 45- 
58.

European Central Bank. 2011. "The Size and Composition of Government Debt in the Euro Area." Occasional Paper Series, 132.

European Commission. 2016. "The Macroeconomic Imbalance Procedure: Rationale, Process, Application: A Compendium." European Commission Institutional Working Paper 039.

https://ec.europa.eu/info/sites/info/files/file_import/ip039_en_2.pdf

Eyraud, Luc, Anja Baum, Andrew Hodge, Mariusz Jarmuzek, Young Kim, Samba Mbaye, and Elif Türe. 2018. "How to Calibrate Fiscal Rules: A Primer" International Monetary Fund, Fiscal Affairs Department How-To Notes, March 2018.

Eyraud, Luc, Victor Duarte Lledó, Paolo Dudine, and Adrian Peralta. 2018. "How to Select Fiscal Rules: A Primer" International Monetary Fund, Fiscal Affairs Department How-To Notes, March 2018.

Faraglia, Elisa, Albert Marcet, and Andrew Scott. 2010. "In Search of a Theory of Debt Management." Journal of Monetary Economics, 57: 821-836.

Farhi, Emmanuel, and Matteo Maggirori. 2018. "A Model of the International Monetary System." Quarterly Journal of Economics, 133(1): 295-355.

Farhi, Emmanuel. 2010. "Capital Taxation and Ownership When Markets Are Incomplete." Journal of Political Economy, 118(5): 908-948.

Farhi, Emmanuel, Christopher Sleet, Iván Werning, and Sevin Yeltekin. 2012. "Non-linear Capital Taxation Without Commitment." Review of Economics Studies, 79: 1469-1493.

Fatás, Antonio, and Ilian Mihov. 2006. "The Macroeconomic Effects of Fiscal Rules in the US States." Journal of Public Economics, 90: 101-117.

Federal Reserve Board. 2018. "Household Debt Service and Financial Obligations Ratio."

https://www.federalreserve.gov/releases/housedebt/default.htm (accessed June 6, 2018)

Feenstra, Robert C., Robert Inklaar, and Marcel P. Timmer. 2015. "The Next Generation of the Penn World Table." American Economic Review, 105(10), 31503182.

www.ggdc.net/pwt / (accessed June 6, 2018)

Fernández-Villaverde, Jesús, Luis Garicano, and Tano Santos. 2013. "Political Credit Cycles: The Case of the Eurozone." Journal of Economic Perspectives, 27(3): 145-166.

Frankel, Jeffrey, and Jesse Schreger. 2013. "Over-Optimistic Official Forecasts and Fiscal Rules in the Eurozone." Review of World Economics, 149(2): 247-272. 
Funke, Manuel, Moritz Schularick, and Christoph Trebesch. 2016. "Going to Extremes: Politics afer Financial Crises, 1870-2014." European Economic Review, 88: 227-260.

Galperti, Simone. 2018. "A Theory of Personal Budgeting." Theoretical Economics, forthcoming.

Geanakoplos, John. 2008. "Overlapping Generations Models of General Equilibrium." In The New Palgrave Dictionary of Economics, Second Edition, edited by Steven N. Durlauf and Lawrence E. Blume, 1-29. London: Palgrave MacMillan.

Geerolf, François. 2017. "Reassessing Dynamic Efficiency." Unpublished. https://fgeerolf.github.io/r-g.pdf

Grembi, Veronica, Tommaso Nannicini, and Ugo Troiano. 2016. "Do Fiscal Rules Matter?" American Economic Journal: Applied Economics, 8(3): 1-30.

Guvenen, Fatih, Serdar Ozkhan, and Jae Song. 2014. "The Nature of Countercyclical Income Risk." Journal of Political Economy, 122(3): 621-660.

Halac, Marina and Pierre Yared. 2014. "Fiscal Rules and Discretion under Persistent Shocks." Econometrica, 82(5) 1557-1614.

Halac, Marina and Pierre Yared. 2016. "Commitment vs. Flexibility with Costly Verification." NBER Working Paper 29936.

Halac, Marina and Pierre Yared. 2017. "Fiscal Rules and Discretion under Self-Enforcement." NBER Working Paper 23919.

Halac, Marina and Pierre Yared. 2018a. "Fiscal Rules and Discretion in a World Economy." American Economic Review, 108(8): 2305-2334.

Halac, Marina and Pierre Yared. 2018b. "Instrument-Based vs. Target-Based Rules." NBER Working Paper 24496.

Hamilton, James D. 2014. "Off-Balance-Sheet Federal Liabilities." Cato Papers on Public Policy, 3: 1-40.

Hatchondo, Juan Carlos, Leonardo Martinez, and Francisco Roch. 2017. "Fiscal Rules and the Sovereign Default Premium." Unpublished.

https://drive.google.com/file/d/0B28k8Kom2VDBZzhGQnFLeVFCLUE/view

He, Zhiguo, Arvind Krishnamurthy, and Konstantin Milbradt. 2018. "A Model of Safe Asset Determination." American Economic Review, forthcoming.

Hébert, Benjamin and Jesse Schreger. 2017. "The Costs of Sovereign Default: Evidence from Argentina." American Economic Review, 107(10), 3119-3145.

Hertzberg, Andrew. 2016. "Time-Consistent Individuals, Time-Inconsistent Households." Unpublished.

https://www0.gsb.columbia.edu/faculty/ahertzberg/papers/HH_Paper_Sept_2016_v9.pdf 
Holmström, Bengt. 1977. "On Incentives and Control in Organizations." PhD diss, Stanford University.

Holmström, Bengt. 1984. "On the Theory of Delegation." In Bayesian Models in Economic Theory, edited by Marcel Boyer and Richard Kihlstrom, 115-41. Amsterdam: North-Holland.

Holmström, Bengt, and Jean Tirole. 1998. "Private and Public Supply of Liquidity." Journal of Political Economy, 106(1): 1-40.

Ignazi, Piero. 2003. Extreme Right Parties in Western Europe. Oxford: Oxford University Press.

International Monetary Fund. "Fiscal Rule Dataset." International Monetary Fund Fiscal Affairs Department.

http://www.imf.org/external/datamapper/fiscalrules/map/map.htm (accessed June 6, 2018).

Jackson, Matthew O., and Leeat Yariv. 2014. "Present Bias and Collective Dynamic Choice in the Lab." American Economic Review, 104(12): 4184-4204.

Jackson, Matthew O., and Leeat Yariv. 2015. "Collective Dynamic Choice: The Necessity of Time Inconsistency." American Economic Journal: Microeconomics, $7(4): 159-178$.

Jacobson, Gary C. 2015. "It's Nothing Personal: The Decline of the Incumbency Advantage in US House Elections." Journal of Politics, 77(3): 861-873.

Karantounias, Anastasios G. 2018. "Optimal Fiscal Policy with Recursive Preferences." Review of Economic Studies, forthcoming.

Krusell, Per, and Anthony A. Smith Jr. 2003. "Consumption-Savings Decisions with Quasi-Geometric Discounting." Econometrica, 71(1): 365-375.

Laibson, David. 1997. "Golden Eggs and Hyperbolic Discounting." Quarterly Journal of Economics, 112(2): 443-478.

Leahy, Joe. 2016. "What Is Brazil's President Dilma Rousseff Accused Of?" Financial Times, May 12, 2016.

Lizzeri, Alessandro, and Leeat Yariv. 2017. "Collective Self-Control." American Economic Journal: Microeconomics, 9(3): 213-244.

Lizzeri, Alessandro. 1999. "Budget Deficits and Redistributive Politics." Review of Economic Studies, 66: 909-928.

Lledó, Victor, Sungwook Yoon, Xiangming Fang, Smaba Mbaye, and Young Kim. 2017. "Fiscal Rules at a Glance." International Monetary Fund Background Paper. 
Lohmann, Susanne. 1992. "Optimal Commitment in Monetary Policy: Credibility vs. Flexibility." American Economic Review, 82(1): 273-286.

Lucas Jr., Robert E., and Nancy L. Stokey. 1983. "Optimal Fiscal and Monetary Policy in an Economy without Capital." Journal of Monetary Economics, 12: 55-93.

Lustig, Hanno, Christopher Sleet, and Sevin Yeltekin. 2008. "Fiscal Hedging with Nominal Assets." Journal of Monetary Economics, 55: 710-727.

Mankiw, N. Gregory 2000. "The Savers-Spenders Theory of Fiscal Policy." American Economic Review, 90(2): 120-125.

Mankiw, N. Gregory, Matthew Weinzierl, and Danny Yagan. 2009. "Optimal Taxation in Theory and in Practice." Journal of Economic Perspectives, 23(4): 147-174.

McCarty, Nolan, Keith T. Poole, and Howard Rosenthal. 2008. Polarized America: The Dance of Ideology and Unequal Riches. Cambridge: MIT Press.

Melumad, Nahum D., and Toshiyuki Shibano. 1991. "Communication in Settings with No Transfers." RAND Journal of Economics, 22(2): 173-198.

Moser, Christian, and Pedro Olea de Souza e Silva. 2017. "Optimal Paternalistic Savings Policies." Columbia Business School Research Paper No. 17-51.

Müller, Andreas, Kjetil Storeletten, and Fabrizio Zilibotti. 2016. "The Political Color of Fiscal Responsibility." Journal of the European Economic Association, 14(1): 252-302.

Obstfeld, Maurice. 2013. "On Keeping Your Powder Dry: Fiscal Foundations of Financial and Price Stability." Monetary and Economic Studies, 31: 25-37.

Organisation for Economic Cooperation and Development. "Elderly Population."

https://data.oecd.org/pop/elderly-population.htm (accessed June 6, 2018).

Organisation for Economic Cooperation and Development. "Revenue Statistics."

https://stats.oecd.org/index.aspx?DataSetCode=rev (accessed June 6, 2018).

Organisation for Economic Cooperation and Development. "Social Expenditure Database."

http://www.oecd.org/social/expenditure.htm (accessed June 6, 2018).

Organisation for Economic Cooperation and Development. 2017. "Pensions at a Glance 2017."

https://www.oecd-ilibrary.org/social-issues-migration-health/pensions-at-a-glance-2017/oldage-dependency-ratio_pension_glance-2017-22-en (accessed June 6, 2018). 
Parker, Kim. 2012. "The Big Generation Gap at the Polls Is Echoed in Attitudes on Budget Tradeoffs." Pew Research Center Working Paper.

http://assets.pewresearch.org/wp-content/uploads/sites/3/2012/12/FINAL_policies_report.pdf

Persson, Torsten, and Lars E.O. Svensson. 1989. "Why a Stubborn Conservative Would Run a Deficit: Policy with Time-Inconsistent Preferences." Quarterly Journal of Economics, 104(2): 325-345.

Persson, Torsten, and Guido Tabellini. 2004. "Constitutional Rules and Fiscal Policy Outcomes." American Economic Review, 94(1): 25-45.

Phelps, E.S., and R. A. Pollak. 1968. "On Second-Best National Saving and Game-Equilibrium Growth." Review of Economic Studies, 35(2): 185-199.

Philippon, Thomas, and Ariell Reshef. 2012. "Wages and Human Capital in the U.S. Finance Industry: 1909-2006." Quarterly Journal of Economics, 127(4): 1551-1609.

Piguillem, Facundo, and Alessandro Riboni. 2018. "Fiscal Rules as Bargaining Chips." Einaudi Institute of Economics and Finance Working Papers Series 1804.

Piguillem, Facundo, and Anderson Schneider. 2016. "Coordination, Efficiency and Policy Discretion." Einaudi Institute of Economics and Finance Working Papers Series 1306.

Poterba, James M. 1995. "Capital Budgets, Borrowing Rules, and State Capital Spending." Journal of Public Economics, 56: 165-187.

Poterba, James M. 1996. "Budget Institutions and Fiscal Policy in the U.S. States." American Economic Review, 86(2): 395-400.

Poterba, James M. 1994. "State Responses to Fiscal Crises: The Effects of Budgetary Institutions and Politics." Journal of Political Economy, 102(4): 799-821.

Primo, David. 2007. Rules and Restraints: Government Spending and the Design of Institutions. Chicago: University of Chicago Press.

Primo, David. 2010. "Making Budget Rules Bite." Mercatus on Policy, 72: 1-4.

Ramey, Valerie A. 2011. "Can Government Purchases Stimulate the Economy?" Journal of Economic Literature, 49(3): 673-685.

Reinhart, Carmen M., Vincent Reinhart, and Kenneth Rogoff. 2012. "Public Debt Overhangs: Advanced Economy Episodes Since 1800." Journal of Economic Perspectives, 26(3): 69-86.

Reinhart, Carmen M., Vincent Reinhart, and Kenneth Rogoff. 2015. "Dealing with Debt." Journal of International Economics, 96(1): 543-555.

Reinhart, Carmen M. and Kenneth S. Rogoff. 2011. "From Financial Crash to Debt Crisis." American Economic Review, 101 (5): 1676-1706. 
Rogoff, Kenneth. 1985. "The Optimal Degree of Commitment to an Intermediate Monetary Target." Quarterly Journal of Economics, 100: 1169-1189.

Rogoff, Kenneth. 1990. "Equilibrium Budget Cycles." American Economic Review, 80(1): 21-36.

Rogoff, Kenneth, and Anne Sibert. 1988. "Elections and Macroeconomic Policy Cycle." Review of Economic Studies, 55(1): 1-16.

Romer, Christina D., and David H. Romer. 2017. "Why Some Times Are Different: Macroeconomic Policy and the Aftermath of Financial Crises," Economica, 85: $1-40$.

Sabelhaus, John, and Jae Song. 2010. "The Great Moderation in Micro Labor Earnings." Journal of Monetary Economics, 57: 391-403.

Salvi, Michele, Christoph A. Schaltegger, and Lukas Schmid. 2017. "Do Fiscal Rules Cause Lower Debt?" Working Paper.

Shell, Karl. 1971. "Notes on the Economics of Infinity." Journal of Political Economy, 79(5): 1002-1011.

Sleet, Christopher. 2004. "Optimal Taxation with Private Government Information." Review of Economic Studies, 71: 1217-1239.

Song, Zheng, Kjetil Storesletten, and Fabrizio Zilibotti. 2012. "Rotten Parents and Disciplined Children: A Political-Economic Theory of Public Expenditure and Debt." Econometrica, 80(6): 2785-2803.

Strotz, R.H. 1995. "Myopia and Inconsistency in Dynamic Utility Maximization." Review of Economic Studies, 23(3): 165-180.

Tabellini, Guido. 1991. "The Politics of Intergenerational Redistribution." Journal of Political Economy, 99(2): 335-357.

Tabellini, Guido, and Alberto Alesina. 1990. "Voting on the Budget Deficit." American Economic Review, 80(1): 37-49.

Tomz, Michael, and Mark L. J. Wright. 2013. "Empirical Research on Sovereign Debt and Default." Annual Review of Economics, 5(1): 247-272.

Tornell, Aaron, and Philip R. Lane. 1999. "The Voracity Effect." American Economic Review, 89(1): 22-46.

Tran, Mark. 2003. "France and Germany Evade Deficit Fines." The Guardian, 25 November, 2003.

Truger, Achim, and Henner Will. 2013. "The German "debt brake": a shining example for European fiscal policy?" Revue de l'OFCE, 127: 153-188.

U.S. Department of the Treasury, Fiscal Service. Retrieved from FRED, Federal Reserve Bank of St. Louis; 
https://fred.stlouisfed.org/series/ (accessed June 6, 2018)

U.S. Electoral College. "Historical Election Results." National Archives and Records Administration of U.S. Electoral College.

https://www.archives.gov/federal-register/electoral-college/votes/index.html (accessed June 6, 2018).

U.S. Bureau of Economic Analysis. "International Investment Position."

https://www.bea.gov/national/ (accessed June 6, 2018).

U.S. Office of Management and Budget. "Historical Tables".

https://www.whitehouse.gov/omb/historical-tables/ (accessed June 6, 2018).

Velasco, Andrés. 2000. "Debts and Deficits with Fragmented Fiscal Policymaking." Journal of Public Economics, 76: 105-125.

Velasco, Andrés. 1999. "A Model of Endogenous Fiscal Deficits and Delayed Fiscal Reforms." In Fiscal Institutions and Fiscal Performance, edited by James M. Poterba and Jürgen Von Hagen, 37-58. Chicago: University of Chicago Press.

Weingast, Barry R., Shepsle, Kenneth A., and Johnsen, Christopher. 1981. "The Political Economy of Benefits and Costs: A Neoclassical Approach to Distributive Politics." Journal of Political Economy, 89(4): 642-664.

Werning, Iván. 2007. "Optimal Fiscal Policy with Redistribution." Quarterly Journal of Economics, 122(3): 925-967.

Wolter, Kirk, Mark Hansen, Andrea Campbell, and Stephen Ansolabehere. 2013. "2012 NORC Presidential Election Study: Americans' Views on Entitlement Reform and Health Care." Working Paper.

Woo, Jaejoon. 2003. "Economic, Political, and Institutional Determinants of Public Deficits." Journal of Public Economics, 87: 387-426.

Woodford, Michael. 1990. "Public Debt as Private Liquidity." American Economic Review, 80(2): 382-388.

World Bank. "World Development Indicators."

https://data.worldbank.org/products/wdi (accessed June 6, 2018).

Wyplosz, Charles. 2012. "Fiscal Rules: Theoretical Issues and Historical Experiences." In Fiscal Policy After the Financial Crisis, edited by Alberto Alesina and Francesco Giavazzi, 495-529. Chicago: University of Chicago Press.

Yared, Pierre. 2010. "Politicians, Taxes and Debt." Review of Economic Studies, 77: 806-840.

Yared, Pierre. 2013. "Public Debt Under Limited Private Credit." Journal of the European Economic Association, 11(2): 229-245. 